\title{
Castle Conglomerate Unit of the Upper Silesian Basin (Czech Republic and Poland): a record of the onset of Late Mississippian C2 glaciation?
}

\author{
JAKUB JIRÁSEK, LENKA SEDLÁČKOVÁ, MARTIN SiveK, KAREL MARTíNEK \& JANUSZ JURECZKA
}

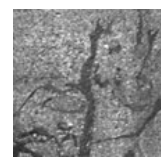

\begin{abstract}
The Castle Conglomerate Unit in the Poruba Member (Early Namurian, Mississippian) is a lithosome composed of coarse-grained sandstones and conglomerates. Its thickness, lithology and extensive area make it unique in the paralic sequence of the Ostrava Formation of the Upper Silesian Basin. The unit was studied on the basis of information from exploratory boreholes, mines and its outcrop at the type locality in the Lučina Valley in Silesian Ostrava. Locally, the unit attains a thickness of up to $115 \mathrm{~m}$ (average $24.4 \mathrm{~m}$ ). Its present-day area is approximately $992 \mathrm{~km}^{2}$. The axis of the conglomerate facies (with character of interbeds) in the unit has a NNE-SSW alignment and coincides with the axis of the basin's maximum subsidence during the sedimentation of the Poruba Member. The maximum aggregate thickness of the conglomerate facies is $60 \mathrm{~m}$; their present-day area of occurrence is approximately $480 \mathrm{~km}^{2}$. The Castle Conglomerate Unit represents deposits of a low-sinuosity river system. The upper part of the multistorey channel fill is characterised by channels filled with sand bedforms and occasional bars. Palaeocurrents show a low spread of vectors, primarily to the NNW. The lower part does not crop out; it is known, therefore, only from boreholes. The presence of the unit's coarse-grained clastics inside the basin filling, which is dominated by siltstone and medium-grained sandstone, indicates a major drop in the base level, which is interpreted here as a drop in the sea level. We correlate this event with the major glacio-eustatic sea level drop at $323 \mathrm{Ma}$ that can be connected with the onset of glaciation interval C2 of the Late Paleozoic Ice Age. Because the resolution of available stratigraphic and geochronologic data is not currently sufficient, an alternative explanation of the tectonic origin cannot be ruled out of the discussion and may also be valid in regard to the active Variscan foreland. - Key words: Ostrava Formation, Upper Silesian Basin, Mississippian, Carboniferous, sedimentology, glaciation, paleovalley.
\end{abstract}

JirÁSEK, J., SedlÁČKovÁ, L., SiveK, M., MARTíneK, K. \& JuRECZKA, J. 2013. Castle Conglomerate Unit of the Upper Silesian Basin (Czech Republic and Poland): a record of the onset of Late Mississippian C2 glaciation? Bulletin of Geosciences 88(4), 893-914 (12 figures). Czech Geological Survey, Prague. ISSN 1214-1119. Manuscript received May 3, 2012; accepted in revised form March 27, 2013; published online October 30, 2013; issued October 31, 2013.

Jakub Jirásek (corresponding author), VŠB - Technical University of Ostrava, Faculty of Mining and Geology, 17. listopadu 15/2172, 70833 Ostrava-Poruba, Czech Republic; jakub.jirasek@vsb.cz•Lenka Sedláčková,VŠB -Technical University of Ostrava, Faculty of Mining and Geology, 17. listopadu 15/2172, 70833 Ostrava-Poruba, Czech Republic; lenka.sedlackoval@vsb.cz • Martin Sivek, VŠB - Technical University of Ostrava, Faculty of Mining and Geology, 17. listopadu 15/2172, 70833 Ostrava-Poruba, Czech Republic; martin.sivek@vsb.cz・Karel Martínek, Charles University in Prague, Faculty of Science, Albertov 6, 12843 Prague 2, Czech Republic; karel@natur.cuni.cz • Janusz Jureczka, Polish Geological Institute, Upper Silesian Branch, Królowej Jadwigi 1, 41-200 Sosnowiec, Poland; jjur@pgi.gov.pl

This study aims to contribute to the on-going debate on the nature of the Late Paleozoic Ice Age. Many studies emerging in recent years have focused on the recognition and timing of glacial periods during the Late Paleozoic and the consequent changes in biota (e.g., Davydov et al. 2010, Fielding et al. 2008, Groves \& Yue 2009, Powell 2008, Rygel et al. 2008, Waters \& Condon 2012). We focus on a marked sedimentary body, the Castle Conglomerate Unit, which may represent a record of the onset of one of the Late Paleozoic glaciations.
The Poruba Member represents the highest lithostratigraphic unit of the Ostrava Formation, which stratigraphically belongs to the Namurian (Arnsbergian). Its lithology has special features that distinguish it from other lithostratigraphical units of the Ostrava Formation. One of the most notable anomalies is the presence of the Castle Conglomerate horizon, which represents a unique accumulation of coarse-grained clastics, atypical for the paralic development of sedimentary fill. Lateral extent of this unit, which is approximately $1,000 \mathrm{~km}^{2}$, average thickness over 
$20 \mathrm{~m}$ and frequent presence of conglomerates with pebble size up to $10 \mathrm{~cm}$ makes it the most prominent horizon of its kind in the Ostrava Formation.

In this study, we focus on studying the Castle Conglomerate Unit ("zlepieniec zamecki” in Polish, "zámecký slepenec" in Czech, hereinafter referred to as CCU). Although there are a number of publications that consider its petrographic composition, especially the pebble material and its granulometric characteristic (e.g., Brieda 1972, Doktor \& Gradziński 1998, Paszkowski et al. 1995), a description of its overall basic geological characteristics throughout its occurrence, i.e., in the Czech and Polish parts of the basin, is still lacking. This publication aims to describe this remarkable sedimentological phenomenon on the basis of maps of the area of occurrence and models of the thickness of its entire lithosome and the conglomerates themselves sensu stricto. Likewise, this work attempts to interpret the findings based on these new results and the sedimentological study of the boreholes and outcrop of this unit.

Similar studies concerning large-scale paleovalleys in Carboniferous are not common, but we can mention works of Gibling \& Wightman (1994), Opluštil (2005), Henry et al. (2010), Belt et al. (2011) or Davies \& Gibling (2011). This study has implication for sequence stratigraphic analysis of the Late Palaeozoic cyclothems and paleoclimatic analysis of the Late Palaeozoic, a topic of long-term interest (e.g., Hampson et al. 1999, Bishop et al. 2010, Davydov et al. 2010, Jerrett et al. 2011, Pointon et al. 2012, Schmitz \& Davydov 2012, Sweet \& Soreghan 2012).

\section{Geological setting}

The Upper Silesian Basin (hereinafter referred to as USB), with its bituminous coal deposits, was formed in the final stages of the evolution of the extensive Moravo-Silesian Palaeozoic Basin in the eastern domain of the Central European Variscides. It was developed in the foreland of the Variscan orogene and became a part of its outer zones, the so-called Rhenohercynicum and Subvariscicum (Grygar \& Vavro 1995, Kumpera \& Martinec 1995).

The post-erosional boundary of the Upper Silesian Basin has a roughly triangular shape that extends from Poland southwards into Czech territory. The area of this important European bituminous coal basin exceeds $7,400 \mathrm{~km}^{2}$. The larger part lies in the territory of Poland, and the smaller part lies in the territory of the Czech Republic.

The basin is filled by some of the youngest sediments overlying the Brunovistulicum (Buła \& Żaba 2005, Kalvoda et al. 2008). These sediments post-date the main phases of the Variscan orogeny and range in age from the Mississippian onwards. The base of the basin is formed by the older sedimentary cover of the Brunovistulicum, spe- cifically sediments of Cambrian, Ordovican, Devonian and Mississippian age. Carboniferous sedimentation begins with pre-flysch carbonates, continues through the marine clastic sediments of the flysch (Culm facies) stage to the coal-bearing terrigenous molasse (Kumpera 1990, Dvořák 1994). Carbonate rocks diminish in the stratigraphically higher parts (by the late Viséan) of the Carboniferous. The basin fill is overlain primarily by Triassic, Neogene (Miocene) and Quaternary and less by Permian and Jurassic sedimentary sequences; in the southern part of the basin, it is also overlain by Neogene deposits of the Carpathian Foredeep and, further south, by nappes of the Outer Carpathians (Jurassic to Paleogene).

As the stratigraphic level increases (i.e., from the west to the east), the intensity of the diagenetic overprint decreases In the Hradec-Kyjovice Formation the vitrinite reflectance $R_{o}$ is generally between 5.5 to $2.0 \%$ (unpublished data); in the Ostrava Formation, $\mathrm{R}_{\mathrm{o}}$ has been reported in the range of 2.0 to $0.5 \%$ (Sivek et al. 2003, Kandarachevová et al. 2009).

The geology of the USB has been described in a number of published papers, as well as unpublished reports. Dopita et al. (1997) summarised the existing knowledge of the geology from the Czech part of the basin. The authors of the latest monograph dealing with the Polish part of the basin are Dembowski (1972a,b), Kotas \& Malczyk (1972a,b) and Porzycki (1972). Recent publications in English on the geology of the USB include Dopita \& Kumpera (1993), Jureczka et al. (2005), Jureczka \& Kotas (1995), Kotas (1995), and Kumpera (1997), among others.

The types of sediments filling the basin, together with their thicknesses and extents, are briefly discussed in papers by Dopita et al. (1997) and Martinec et al. (2005). Coal seams containing bituminous coal in the USB are of the Late Carboniferous (Namurian to Westphalian) age. Two major sedimentary units can be distinguished in the coal-bearing Carboniferous: a paralic facies and a terrigenous facies. The older, paralic type of sedimentation can exist in a wide spectrum of sedimentary environments, from purely continental with transitions to marine, frequently with intercalations of pyroclastic material. This type of sedimentation is characterised by the cyclic alternation of inorganic sediments with coal beds that is known as a cyclothem. The Early Namurian Formation (Ostrava Formation, Paralic Series) consists of the Petřkovice, Hrušov, Jaklovec and Poruba Members (see Fig. 1).

Several authors have reported the cyclicity of the coalbearing sequences in the Ostrava Formation of the USB. Most prominent among these are Prribyl (1954), Jansa \& Tomšík (1960), Zeman (1960) and Havlena (1988), who tried to explain this cyclicity by epeirogenetic movements. Only Skoček (1991) and, later, Gastaldo et al. (2009a) attempted to apply the glacio-eustatic fluctuation of the sea 


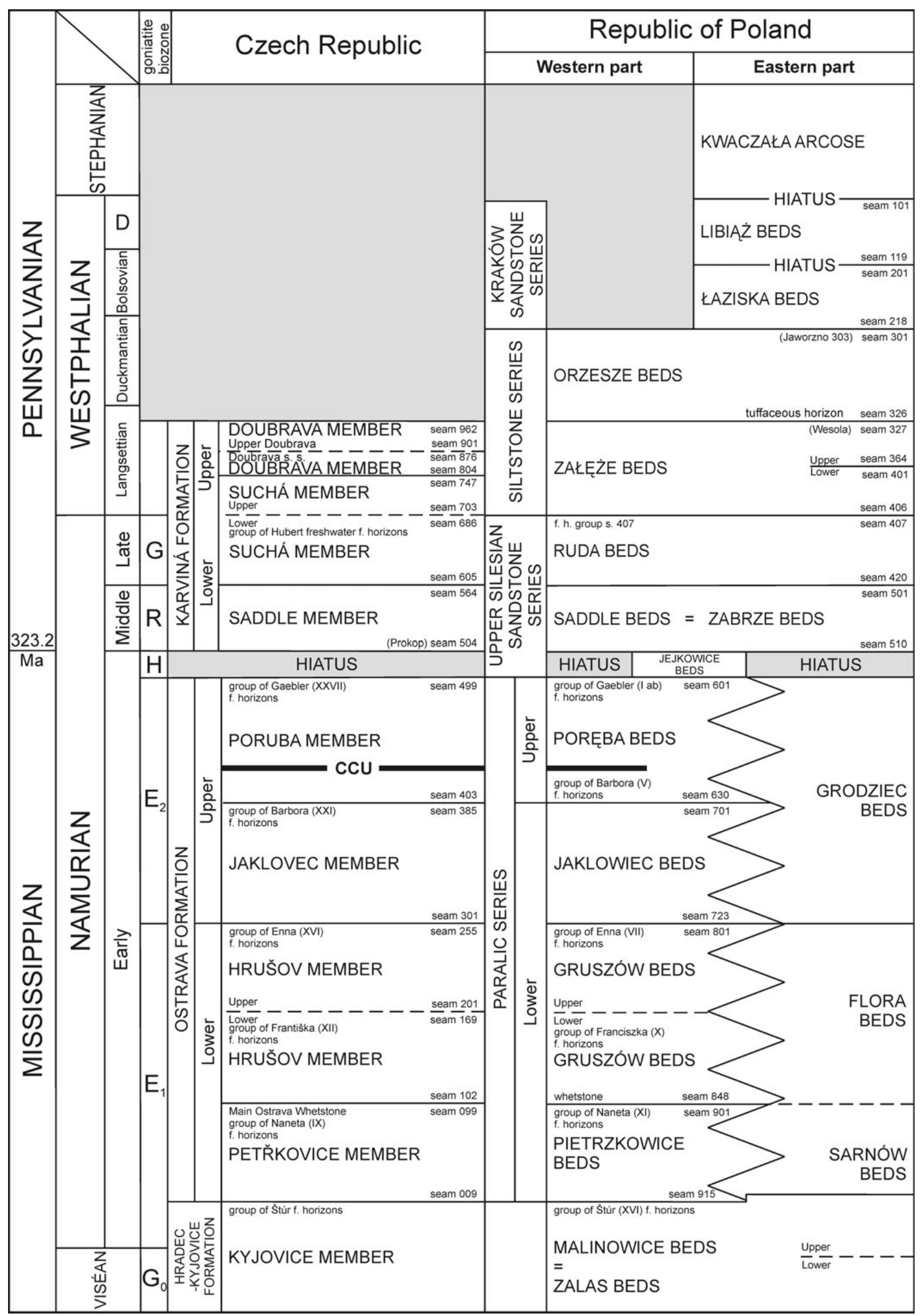

Figure 1. Lithostratigraphic division of the Czech and Polish parts of the Upper Silesian Basin, according to (Polish part) Dembowski (1972a), modified by Jureczka (1988) and Kotas et al. (1988), and (Czech part) Sivek et al. (2003), which was modified. Radiometric dating according to Davydov et al. (2012), goniatite biozones according to Řehoř (1970). Position of the Castle Conglomerate Unit is indicated by bold line. 

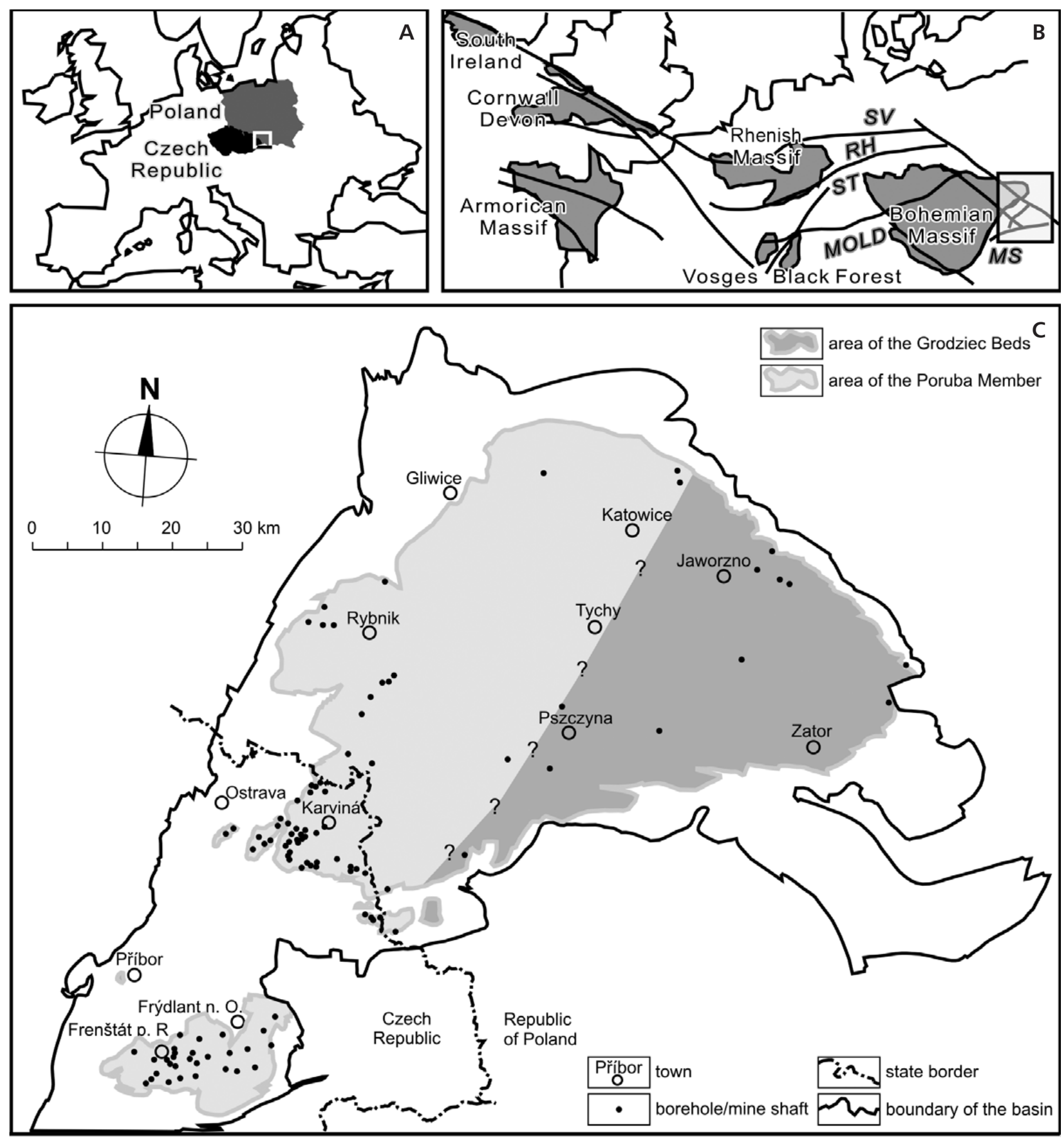

Figure 2. A - location of the Czech Republic and Poland within Europe. $•$ B - location of the Bohemian Massif and the study area within European Variscides. Major tectonic elements: SV - Subvariscan Zone, RH - Rheno-Hercynian Zone, ST - Saxo-Thuringian Zone, MOLD - Moldanubian Zone, MS - Moravo-Silesian Zone (according to Hýlová et al. 2013). C - location of the exploratory boreholes and mine shafts used in the work.

level to explain the origin of cyclothems in the USB. An ideal cycle of the Ostrava Formation consists of (from the base upward): 1. carbonate cemented sandstone or biotitic arkose; 2. aleuropelites, at the top with root casts (seathearth); 3. coal; 4. massive mudstone to siltstone with large plant remains or bituminous muscovitic aleuropelite enclosing fresh-water fauna, sometimes with brackish or marine fauna. The cycle thickness varies from 6 to $20 \mathrm{~m}$; average is $15 \mathrm{~m}$. Cycles of higher order are mesocycles and megacycles (Ostrava Formation comprises 6 megacycles). The studied part of the sedimentary record belongs to the Megacycle F according to Jansa \& Tomšík (1960). 


\section{Material and methods}

The primary data source for creating the data files intended for modelling the development of the Castle Conglomerate Unit are the well-logs of the exploratory boreholes. The exploratory boreholes were realised over a long period of time in the second half of the $20^{\text {th }}$ century. Thus, it is evident that, with respect to developments in boring technology and data interpretation, the data file is very diverse. As a result, it was necessary to approach the boreholes included in this file individually and to re-evaluate the data.

Sixty-two documentation points that describe the complex's complete profile were used to create the models (Fig. 2). Additionally, 63 documentation points, in which the complex was not developed in the corresponding stratigraphic level, were used to form the boundary of the extended unit. All profiles were individually assessed. Apparent stratal thicknesses were converted to true thicknesses at intervals with a specific known inclination. Specifically, the boreholes used to create the models were NP 164, NP 321, NP 339, NP 340, NP 388, NP 416, NP 417, NP 475, NP 477, NP 486, NP 499, NP 522, NP 523, NP 531, NP 533, NP 539, NP 541, NP 544, NP 545, NP 546, NP 550, NP 551, NP 552, NP 554, NP 556, NP 671, NP 672, NP 673, NP 675, NP 687, NP 718, NP 729, NP 818, NP 819, NP 821, NP 822, NP 824, NP 825, NP 826, NP 827, NP 830, NP 840, NP 891, NP 905, NP 906, NP 908, NP 910, 199/XXXIX, 930/XLIII, C-17, C-32/87, D-5/86, D-34/87, D-71/08,D-72/08, D-73/08, D-74/08, D-75/08, D-76/08, D-77/08, D-78/09, D-79/09, D-80/09, ČSM 68/85, ČSM 111/88, ČSM 112/85, SuSto 515/89, SV 2 (Czech Republic) and CieIG-1, G-381, JeIG-1, Je-4, Je-5, Мa-18, Ma-32, Мa-34, Мa-39, Ma-41, Pi-32, RupIG-1, Sum-5 and Wa-2 (Poland). The following cross-adit and mine shaft profiles were also used: Evžen 1, Hedvika 2, Ludvík 3/1, Pokrok 1/3, Václav 1, Zárubek (Hermenegild), Žofie 5/1 (Czech Republic).

To construct the isopach models of the Castle Conglomerate Unit in the basin, the method of bisecting the distances between the positive and the negative boreholes was used. Map outputs were created by program products from Bentley Systems, Inc. - InRoads and MicroStation 8.5. The inner part of the model used interpolation between the triangles constituting known documentation points; the points of each triangle included the last known point, the border and the extrapolated point. In areas without known values adjacent to extrapolated values, the model is estimated by an expert's best judgement (Kandarachevová et al. 2008).

The seam numbering used in the text is from the Czech part of the Upper Silesian Basin (Dopita 1959), whereas the regional chronostratigraphic units used for classifying the Late Carboniferous in Western and Central Europe (Namurian, Westphalian, Stephanian) are used.
The sedimentological study is based on two core logs, four outcrop logs and three outcrop photomosaics. The approach to interpreting the geometric features of facies assemblages (architectural elements) essentially follows that of Miall (1985) and Bridge (1993). The petrology of the primary facies types was also studied in 20 thin sections of core D 80-09 using standard optical transmitted light microscopic techniques.

\section{Characteristics of the Castle Conglomerate Unit}

The aim of this work was to build on previously published data on the Poruba Member and the Castle Conglomerate, which were based on data from the Czech and Polish parts of the basin, to describe the overall geological picture of this remarkable phenomenon. The models are the first interpretation of the development of the Castle Conglomerate Unit and its conglomerate facies in the Upper Silesian Basin. The sedimentological interpretation is also novel.

\section{The unit's definition and boundaries and its position in the Poruba Member}

The first to name the lithosome of sandstones with conglomerate layers the "Castle Conglomerate" was likely Šusta (1928a), in a brief report that immediately preceded the release of the monograph "Coal mines in the Ostrava-Karviná district". In the monograph itself, this name is used by Patteisky \& Folprecht (1928) and Šusta (1928b). Patteisky \& Folprecht (1928) state that Susta named the conglomerate, although no literary source is cited. The facts concerning the first description are not well known by the professional public and are very often cited incorrectly. This rock succession acquired its name from to the surface outcrop, which is located in the vicinity of the Silesian-Ostrava Castle (which was converted to a chateau between 1534 and 1548). Works published prior to 1928 (e.g., Petrascheck 1910) present this horizon of conglomerates with coarsegrained sandstones but do not name it specifically.

The Castle Conglomerate Unit is understood to be a lithosome of coarse- to medium-grained sandstones with conglomerate facies. It is located in the lower part of the Poruba Member (Namurian) of the Ostrava Formation of the Upper Silesian Basin (Fig. 3). Its base is primarily erosive and is situated at approximately the same stratigraphic level throughout the basin, i.e., above the Filip (403) coal seam group. In the Ostrava part of the basin, 3-4 incomplete cycles of the František (413) seam above the Filip coal seam group are preserved (Brieda 1972; Fig. 4). The Frenštát part of the basin (southernmost part of the USB), where the Castle Conglomerate Unit totally eroded the 
basal part of the Poruba Member and a significant part of the Jaklovec Member (boreholes NP 821, NP 822, NP 824, NP 826 and NP 552 at Fig. 5), is exceptional.

The unit's roof is blurred, forming its transition to the finer-grained sediments. In the unit's roof, there was a previously developed, easily identifiable sequence of marine sediments of the Gabriela marine horizon. Locally developed coal seams were observed between the marine sediments and the unit's roof, as well as within the unit itself.

CCU itself can be locally used as an important correlation horizon. Nevertheless, the faunistic horizon Gabriela, which lies in the unit's nearby roof, is used for confirmation of the correct identification in boreholes. The marine horizon Gabriela is the stratigraphically lowest faunistic horizon of the Koks faunistic horizon group (XXIII) and is the most significant one within it. It is developed on the top of the Gabriela (418) coal seam. Its faunistic assemblage is very variable. Bivalves predominate over cephalopods (mostly Goniatitida) and gastropods (represented by Bellerophontacea) and were described by Řehoř \& Řehořová (1985).

\section{Area of the unit's occurrence and unit's outcrops}

To understand the origin and development of the Castle Conglomerate Unit, models of its area and thickness have been created that include the area and the overall thickness of the conglomerate layers in this unit (Fig. 7). The Castle Conglomerate Unit is not developed in the entire area of the Poruba Member's development in the Upper Silesian Basin (Fig. 2). The greatest thickness occurs at the western post-erosive border, where, in certain locations, the thickness exceeds $100 \mathrm{~m}$. The area of maximum thickness is located in the Jejkowice and Chwałowice Brachysynclines (west of the town Rybnik) and in the Ostrava, Petryald and western segment of the Karviná parts of the basin (approximately between the cities of Ostrava and Haviŕrov). The unit's maximum thickness is thus located west of the Orlová Structure. In the areas of the unit's maximum thickness, 1 to 4 seam cycles occur in some places (seams 413, $415,416,417)$. Towards the east, the unit pinch out far from the Grodziec Bed's transition area (Fig. 7, see below). Additionally, as the unit's thickness decreases to the east, signs of its cyclic structure gradually disappear.

The area in which the conglomerate facies are developed is approximately $480 \mathrm{~km}^{2}$ and constitutes approximately $48 \%$ of the unit's total area. The model of the conglomerate bodies' development in the unit (Fig. 7) has features similar to the development of the entire unit. The maximum thickness (and number) of the conglomerate beds is situated at the western post-erosive border of the Poruba Member. The greatest thickness of the conglomerate beds occurs in the Petřvald sub-basin and in the western part of the Karviná sub-basin (approximately between the cities of Ostrava, Havírov and Karviná - Fig. 6), where their number reaches 6 and their combined thickness reaches $60 \mathrm{~m}$. In these places, the conglomerate layers constitute up to $67 \%$ of the total thickness of the unit. Further to the east, behind the Orlová Structure, the conglomerate bodies of the CCU sharply pinch out. In the same direction, the sandstones become finer, and the primarily coarsegrained sandstones towards the east become mediumgrained to fine-grained. This development was known to the authors of earlier work (e.g., Brieda 1972, Doktor \& Gradziński 1998, Strakošová 1973, Ševčík 1989).

In the eastern part of the Upper Silesian Basin, the Poruba Member is present in the development of the socalled Grodziec Beds. Doktorowicz-Hrebnicki (1935) reported a relatively general definition of these beds around the city of Dąbrowa Górnicza. Most likely, they represent the equivalent of amalgamated Jaklovec and Poruba Members in development, with a very low coal-bearing capacity and reduced thickness. The hypothetical extent of the Grodziec Beds is shown in Fig. 2. The Castle Conglomerate Unit has not been identified beyond this threshold, and its existence is very unlikely. In the framework of the Grodziec Beds, the sediments of the Gabriela marine horizon are not present; thus, the occurrences of sandstone bodies cannot be correlated with the Castle Conglomerate Unit.

Because of its greater resistance to erosion, the Castle Conglomerate Unit is preserved in outcrop in several places. The most extensive series of outcrops stretches in a belt in the valley on the right bank of the Lučina River from the bridge at Podzámčí Street (N 49 ${ }^{\circ} 49^{\prime} 45.7^{\prime \prime}$ E $\left.018^{\circ} 18^{\prime} 05.6^{\prime \prime}\right) 760 \mathrm{~m}$ eastward along the coordinates $\mathrm{N} 49^{\circ} 49^{\prime} 37.8^{\prime \prime} \mathrm{E} 018^{\circ} 18^{\prime} 41.6^{\prime \prime}$ (Fig. 2). The largest two outcrops are at N $49^{\circ} 49^{\prime} 44.5^{\prime \prime}$ E $018^{\circ} 18^{\prime} 15.0^{\prime \prime}$ (Fig. 11) and $\mathrm{N} 49^{\circ} 49^{\prime} 40.7^{\prime \prime} \mathrm{E} 018^{\circ} 18^{\prime} 24.4^{\prime \prime}$. This series of outcrops, which is close to the Silesian-Ostrava Castle, was the reason the horizon was given its name and is described in detail in following chapter.

Žídková et al. (1997) describe the road cut by the Trojice Mine, Lučina Valley, vicinity of the Václav Colony and neighbourhood of the church wall in Orlová as another outcrops of the unit. Through critical assessment based on a study of uncovered geological maps and a lithologic correlation of the mine's cross-sections and profiles, it can be said that, apart from the Lučina Valley, outcrops of the Castle Conglomeration may also be found at the Žofie Mine. Due to the high degree of anthropogenic changes to the surface, the possible presence of other CCU outcrops is very small.

\section{Sedimentary facies and architectures}

The Ostrava Formation is composed almost entirely of cyclothems formed by coal seams, fine- to medium-grained 
Jakub Jirásek et al. • Castle Conglomerate Unit of the Upper Silesian Basin

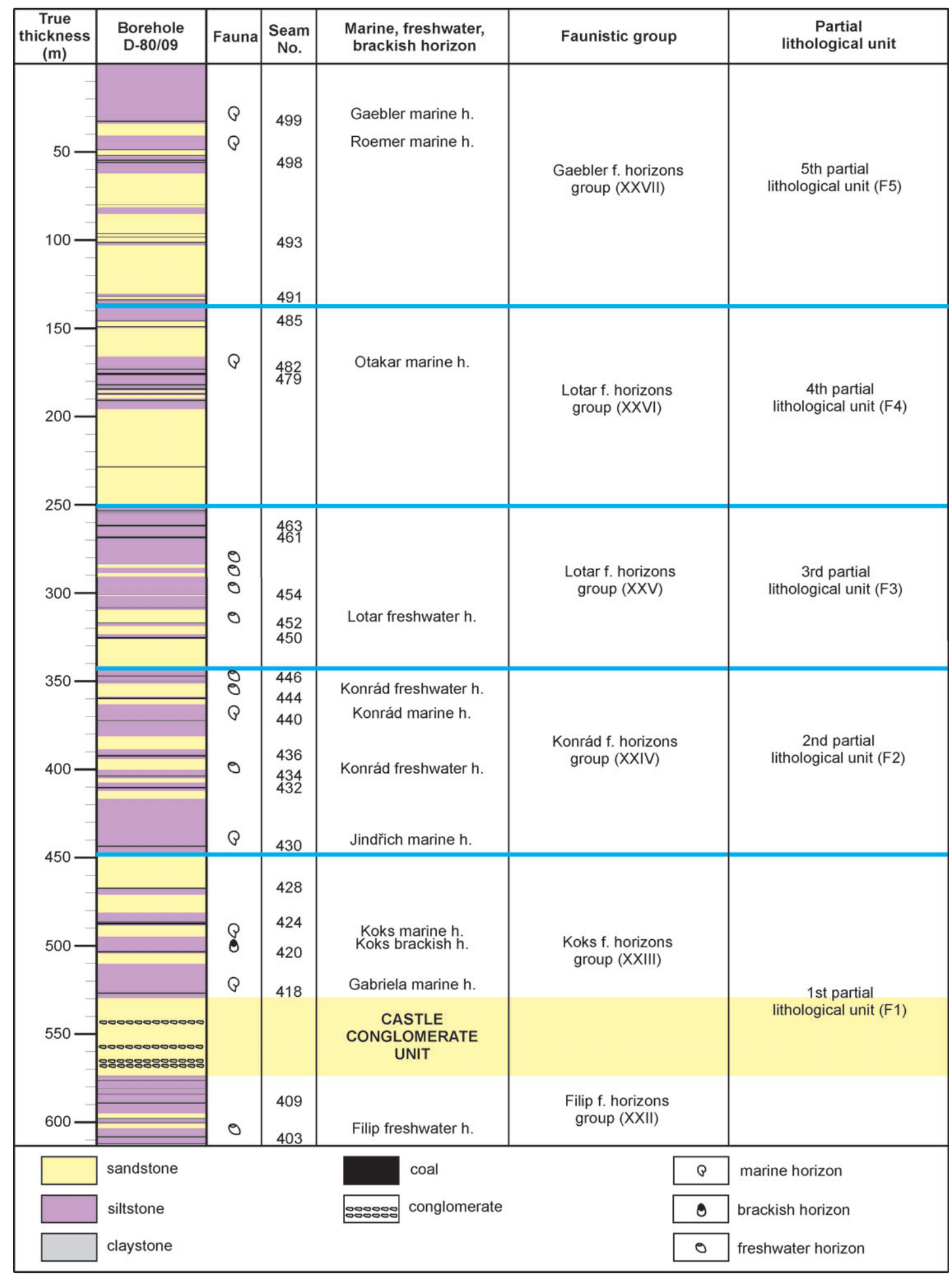

Figure 3. Stratigraphic position of the Castle Conglomerate Unit in simplified borehole D-80/09 in the Ostrava part of the Upper Silesian Basin. The position of the borehole is indicated in Fig. 2. 


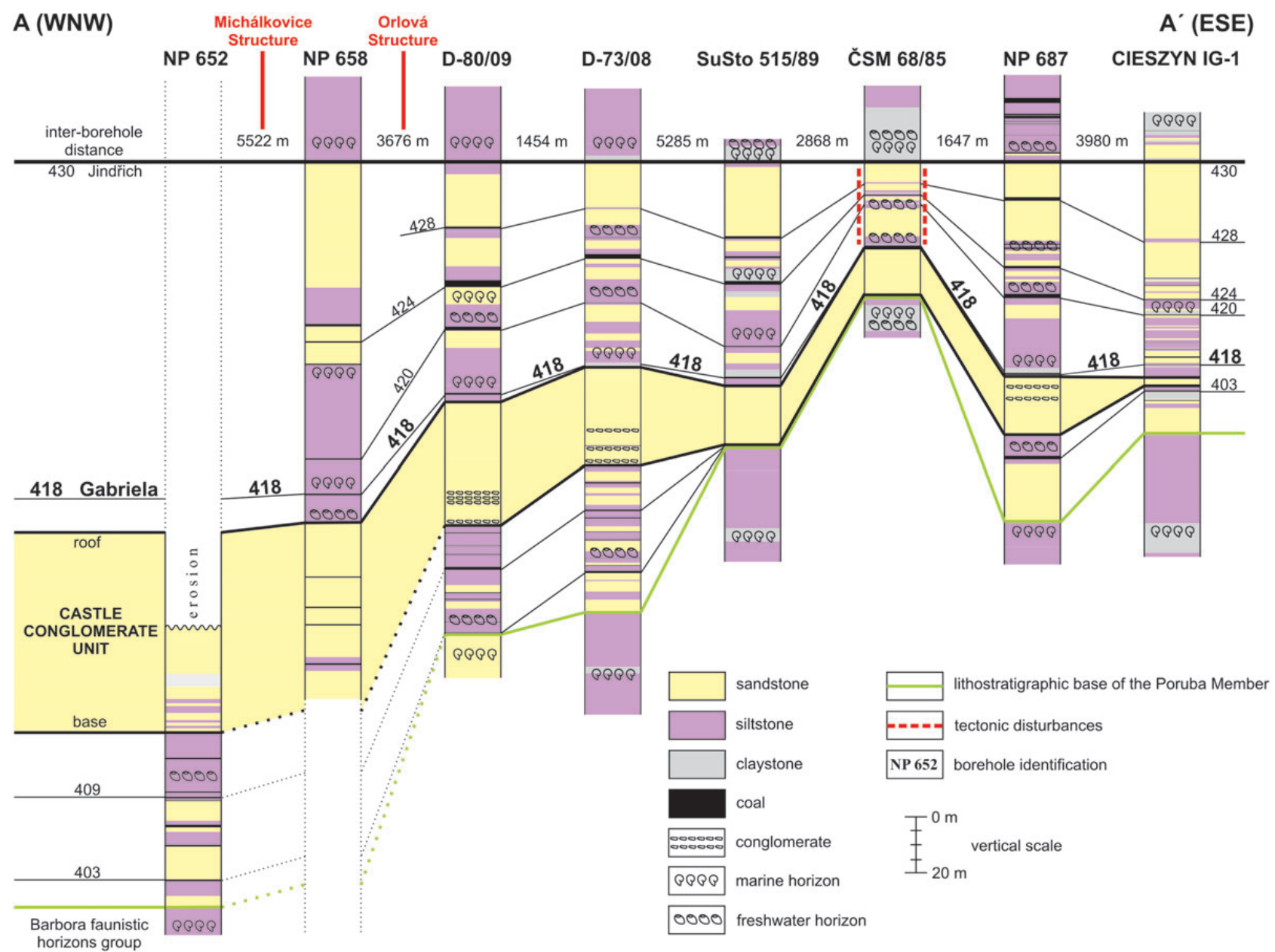

Figure 4. Development of the lower part of the Poruba Member with the Castle Conglomerate Unit in the cross-section A-A' (from Ostrava to Karviná part of the basin). The position of the cross-section is indicated in Fig. 7. Boreholes are levelled to Jindřich marine horizon.

sandstones with ripples, flaser bedding, wavy bedding, load casts (tidal flat deposits), mudstones with fauna (marine or brackish or freshwater) and occasional fluvial deposits (mudstones, fine- to medium-grained sandstones); for example Havlena (1982), Kędzior et al. (2007). The Castle Conglomerate Unit is a unique lithosome within this relatively fine-grained paralic succession due to its thickness, which averages more than $20 \mathrm{~m}$; its lithology, which is primary medium- to coarse-grained sandstones and conglomerates; and also its lateral extent, which can be traced over an area of approximately $1,000 \mathrm{~km}^{2}$.

\section{Facies}

Four main facies were distinguished within the Castle Conglomerate unit (CGL1, CGL2, SST1 and SST2), and one facies (HET) of the underlying and overlying succession was identified (Fig. 8):

Facies CGL1. - Clast-supported conglomerate: Pebble to cobble medium- to well-sorted oligomictic and polymictic conglomerates could be either clast-supported or matrixsupported. The matrix is formed by coarse-grained, medium- to well-sorted sandstone, the clasts of which are mostly subangular. Pebbles and cobbles are usually medium- to well-rounded and primarily quartz (monocrystalline as well as polycrystalline, Fig. 10A); chert, volcanics and crystalline rocks can also be present. Rip-up mudstone, siltstone and coal clasts are very common (Fig. 9A, B). Conglomerates are mostly cross-bedded, but they can also be massive. Individual beds range in thickness from centimetres to $1 \mathrm{~m}$, with sharp or erosional bases. They form successions up to $4 \mathrm{~m}$ thick, which may show fining upwards trends; the uppermost parts may be formed by coarse-grained sandstone with a pebble admixture.

Facies CGL2. - Matrix-supported conglomerate: The medium-sorted oligomictic and polymictic matrix-supported conglomerates are usually pebble and occasionally cobble. The matrix is formed by medium- to coarse-grained 


\section{B (WSW)}

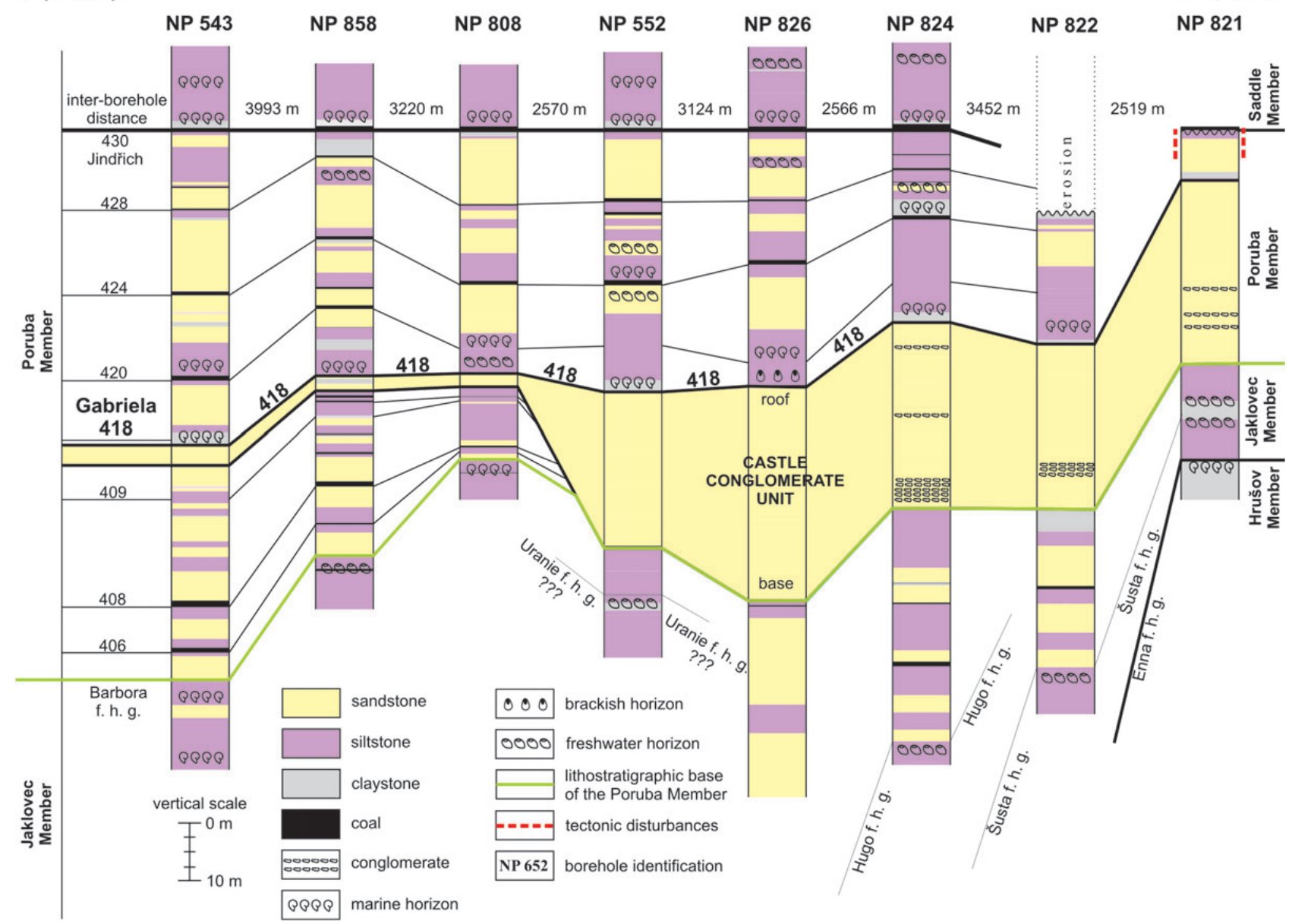

Figure 5. Development of the lower part of the Poruba Member with the Castle Conglomerate Unit in the cross-section B-B' (Frenštát area). The position of the cross-section is indicated in Fig. 7. Boreholes are levelled to Jindřich marine horizon.

medium-sorted clayey silty sandstone, the clasts of which are mostly subangular. Pebbles and cobbles are usually medium- to well-rounded and primarily quartz (monocrystalline as well as polycrystalline); chert, volcanics and crystalline rocks can also be present. Rip-up mudstone, siltstone and coal clasts are very common (Fig. 9C). Conglomerates are cross-bedded. Individual beds are 0.8 to $1.4 \mathrm{~m}$ thick, with sharp bases.

Facies SST1. - Cross-bedded sandstone: Medium to coarse-grained sandstones are usually medium to well sorted with subangular clasts (Fig. 10B). Cross-bedding, pebble admixture and mudstone, siltstone and coal rip-up clasts are very common (Figs 9D-F, 10C). Individual beds are $\mathrm{dm}$ to $2.8 \mathrm{~m}$ thick and have sharp bases. They form successions up to $11 \mathrm{~m}$ thick.

Facies SST2. - Flaser-bedded sandstone: The medium to coarse-grained clayey silty sandstones are usually medium sorted with moderately rounded clasts. The most common sedimentary structure is flaser bedding, but it may also be massive. Mudstone, siltstone and coal rip-up clasts are common as well as mud, silt and, especially, coal drapes (Figs 9G, 10D, E). High mud content up to the thin sandy mud layers can be present locally. Individual beds are $0.6 \mathrm{~m}$ to $2.2 \mathrm{~m}$ thick. They form successions up to $3.9 \mathrm{~m}$ thick.

Facies HET. - Heterolithics: Heterolithic facies are dominated by siltstones and fine-grained sandstones (Figs 9H, 10F); mudstones and medium- to coarse-grained sandstones are less abundant. Sandstones are moderately sorted and moderately to well rounded. Individual lithologies alternate frequently, forming $\mathrm{mm}, \mathrm{cm}$ and $\mathrm{dm}$ thick beds and laminae. Lamination, flaser bedding, lenticular bedding, current ripples, water-escape (convolution) structures, roots and plants are common.

\section{Architectures and vertical succession}

The geometry of the sedimentary bodies was studied at outcrops in the vicinity of the Silesian-Ostrava Castle. Unfortunately, the outcrops represent only the uppermost 8-9 m 
of the Castle Conglomerate Unit, and only sandstone facies SST1 and SST2 are cropping-out (Fig. 8). All sedimentary bodies observed have erosional bases, a channel shape and a through-cross bedded sandstone fill (Fig. 11). It is likely that these bodies represent channel fill sand bedforms. Flat-based bodies, interpreted as sand bars, occur occasionally. Paleocurrent vectors were measured using crossbedding planes; they show a low spread, primarily in the NW-NNW direction.

There is a major erosional surface at the base of the Castle Conglomerate Unit and a general fining upwards trend. The main, thickest (up to $4 \mathrm{~m}$ thick), conglomeratic facies are at the base of the succession, while the top is formed by the thickest sandstone facies succession (up to $8 \mathrm{~m}$ thick). Five fining upwards subunits were distinguished. They are formed by the CGL1 and CGL2 facies at the base, overlaid the by SST1 and SST2 sandstone facies. The conglomeratic bases of these subunits are erosional. Thin (5-10 cm thick) mudstone and coal interbeds are interpreted as larger rip-up clasts because no roots are present below the coal, and the core is only $4 \mathrm{~cm}$ in diameter.

\section{Petrographic description and identification of the pebble material}

The majority of the published studies concerning the Castle Conglomerate Unit have paid a great deal of attention to its petrographic composition. Among them, the most important are the works of Brieda (1972), Kumpera \& Martinec (1995), Paszkowski (1994), Paszkowski et al. (1995), Patteisky \& Folprecht (1928), Petrascheck (1910) and Zeman \& Kupka (1958).

The Castle Conglomerate Unit can be characterised as a lithosome of coarse- to medium-grained (fine in places) feldspathic sandstone containing up to 6 layers of polymictic conglomerates in places. The conglomerate layers do not have a fixed stratigraphic position and do not form continuous layers; instead, the layers form long elongated lenticular bodies. Various authors have reported the maximum pebble size from different places in the range of 5 to $10 \mathrm{~cm}$. The pebbles are well rounded (Fig. 9A-C).

The most detailed petrography of the conglomerate clasts is described by Paszkowski et al. (1995). Approximately $60 \%$ of the clasts are vein quartz (older works from the Czech part of the basin present $80 \%$ to $95 \%$ ), whereas approximately $15 \%$ of the clasts are metamorphic rocks (gneisses, quartz-muscovite schists, deformed granitoids and pegmatites), $10 \%$ are cherts, 5\% are clastic silicic rocks (mostly quartz arenites), 5\% are metacherts, and 5\% are metaquartzites. The accessories include silicified peat, silicified limestones, phosphorites and jaspilites. Brieda (1972) described coal fragments from the unit and the abundant occurrence of carbonised plant fragments at the base of each cycle of the František (413) seam in the Ostrava part of the basin. Of the transparent heavy minerals in the unit, garnet and apatite dominated, subordinated by rutile (Kumpera \& Martinec 1995).

Of the other conglomerates in the Upper Silesian Basin, the fossiliferous clasts were dated (Paszkowski et al. 1995), although these clasts were not, unfortunately, from the Castle Conglomerate Unit. From the Saddle Member and other stratigraphically higher units of the USB, the chert clasts acritarch assemblages indicate an Early Silurian age, radiolarite clasts with Radiolaria represent the Late Devonian age, graptolites from the chert clasts of the Łaziska Beds represent the Early Silurian (Llandovery), chert clasts with conodonts from the Mudstone and Sandstone Cracow Series are Late Devonian (Famenian) or Early Carboniferous (Tournaisian), graptolites from chert clasts from the Łaziska Beds represent the Early Silurian (Llandovery), and trace fossils from quartz arenite clasts from Łaziska Beds represent the Cambrian or, more likely, Ordovican. It is likely that the clasts with the same petrographic composition in the Castle Conglomerate Unit will have the same source areas and, thus, an identical age.

\section{Discussion}

\section{Lateral extent of the unit}

The models of the thickness of the Castle Conglomerate Unit and its conglomerate layers sensu stricto (Fig. 7) clearly show that the unit, in its classic form, is developed in the maximum subsidence axis of the Poruba Member. Towards the north and the east, its overall thickness declines, and the conglomerate layers disappear. This confirms the local observations of Brieda et al. (1973) from the north of the Ostrava sub-basin and the Petřvald sub-basin and Strakošová (1973) in structural boreholes Stonava SV 2 and Ševčík (1989) from the area of the Dukla Mine. In contrast, its occurrence is significantly larger than that described in the map presented by Doktor \& Gradziński (1998). In the Czech (mines ČSM, Lazy, Darkov) and the Polish areas (e.g., boreholes Cieszyn IG-1 and Ruptawa IG-1), the Castle Conglomerate Unit clearly extends beyond the Orlová Structure, although the majority of the unit is only in a sandstone development without conglomerate facies. The Orlová Structure was not active during the unit's sedimentation. Its later influence mainly consists of the fact that it shortened the Poruba Member by eroding its upper anticlinal part.

\section{Source material and area}

The source area of the material in the unit is almost unknown. On the basis of the petrographic analysis, it is clear 


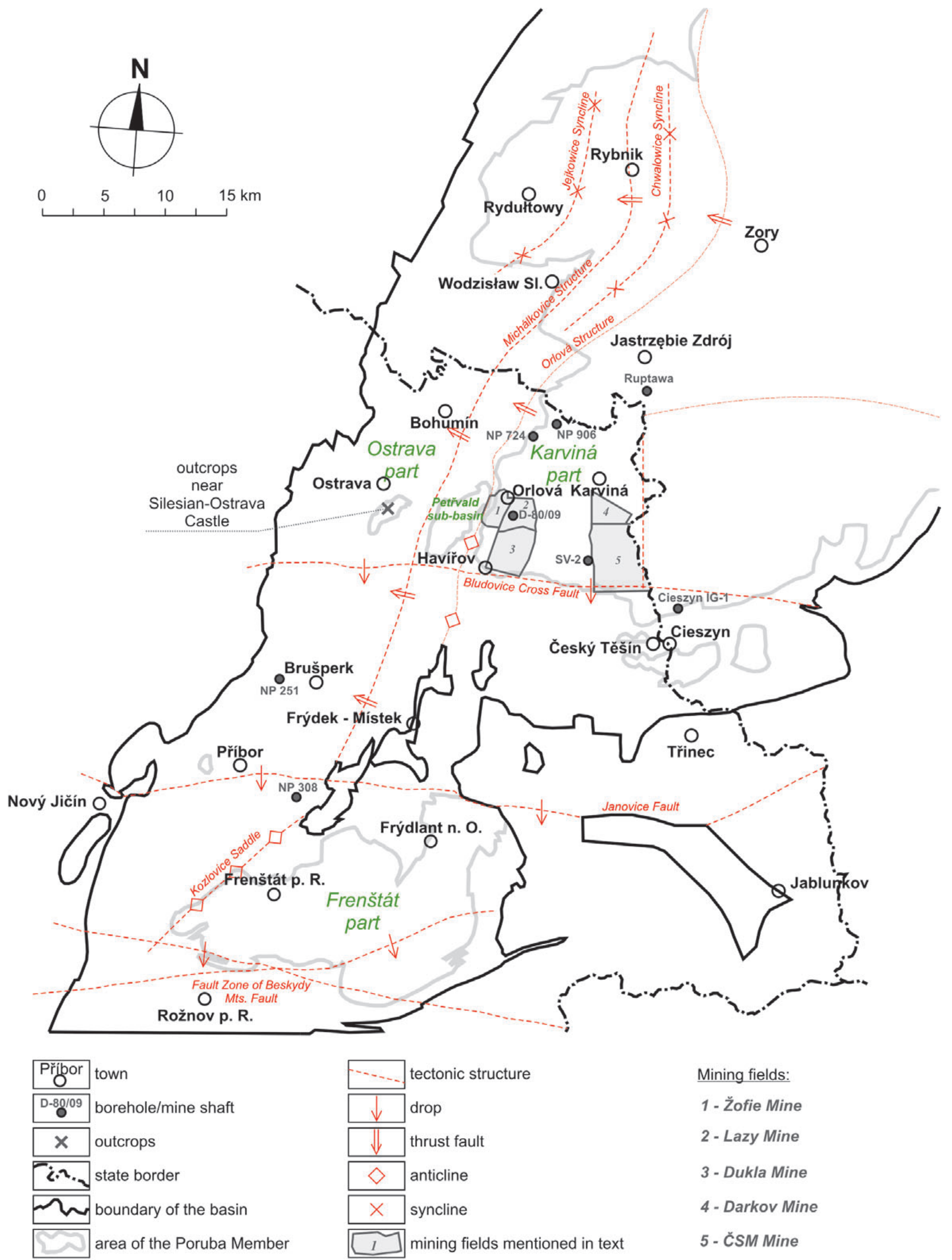

Figure 6. Locations of towns, mining fields, boreholes and important geological structures mentioned in the text. 


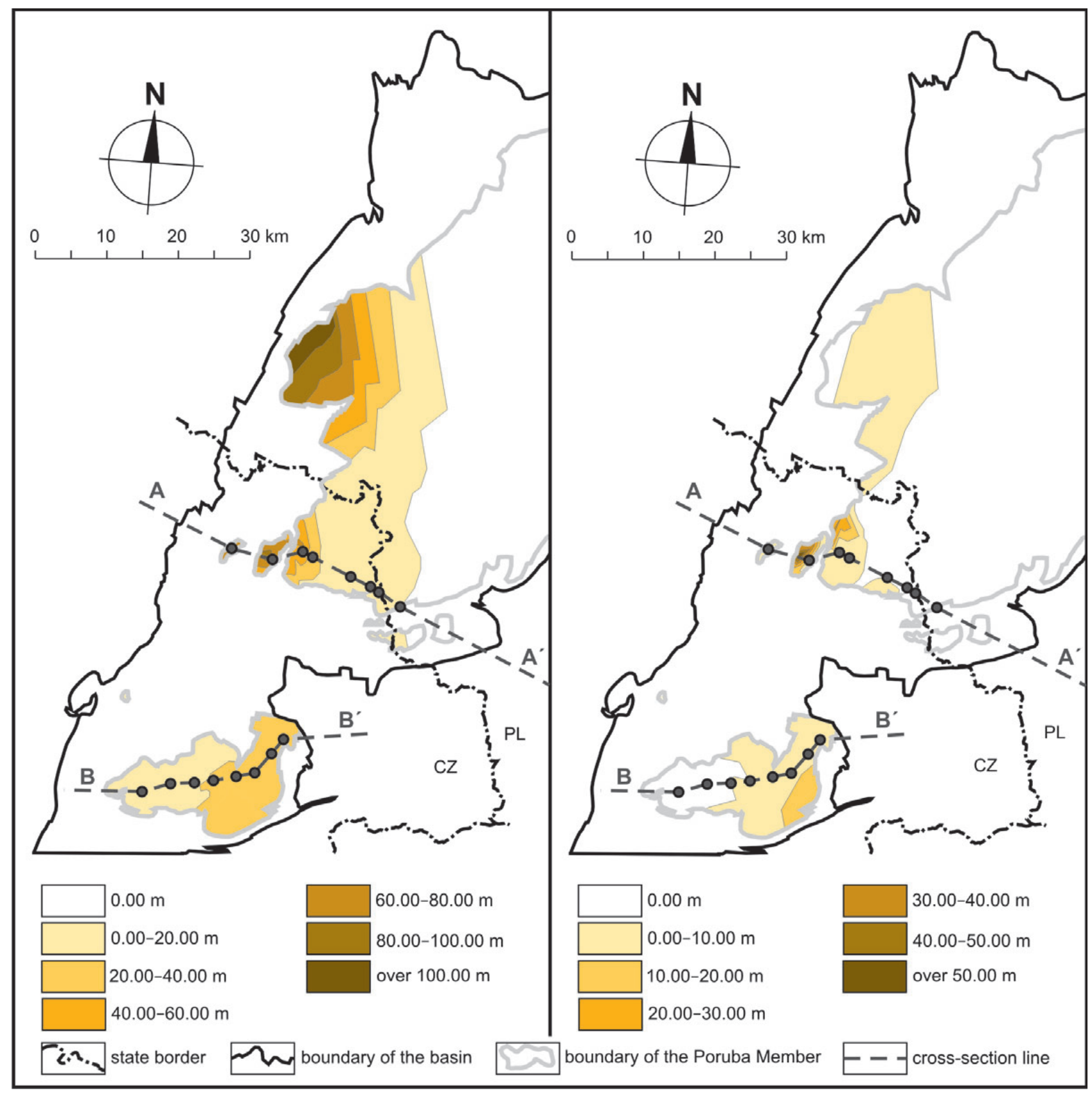

Figure 7. A - model of the area of occurrence and the thickness of the Castle Conglomerate Unit in the Upper Silesian Basin. $\bullet$ B - model of the overall thickness of the conglomerate beds in the Castle Conglomerate Unit.

that, of the identifiable clastic material, material from the crystalline complex in the basin's bedrock predominates, i.e., from the Brunovistulicum and its covering units, which are known in the basement of the southern edge of the Upper Silesian Basin (Buła \& Żaba 2005). The origin of the clasts' other materials can be found in the dissected magmatic arc and other source fields (Świerczewska 1995). A source of coal clasts in the complex is the cannibalism of Carboniferous sediments containing coal seams (Pešek \& Sýkorová 2006). The only absolutely dated mate- rial from the unit is detritic muscovite, which was dated by Banaś et al. (1995) using the K-Ar method to $313.2 \pm$ 7.0 Ma. This result is obviously incorrect because the detritic mica would have to be significantly younger than the Poruba Member itself.

The change in the sandstone composition (size and petrology of the clasts) within the CCU and other sandstones/conglomerates in the Upper Silesian Basin cannot be ascribed only to the long-term evolution of the source areas. The distinct differences are likely to have 
core D 80-09

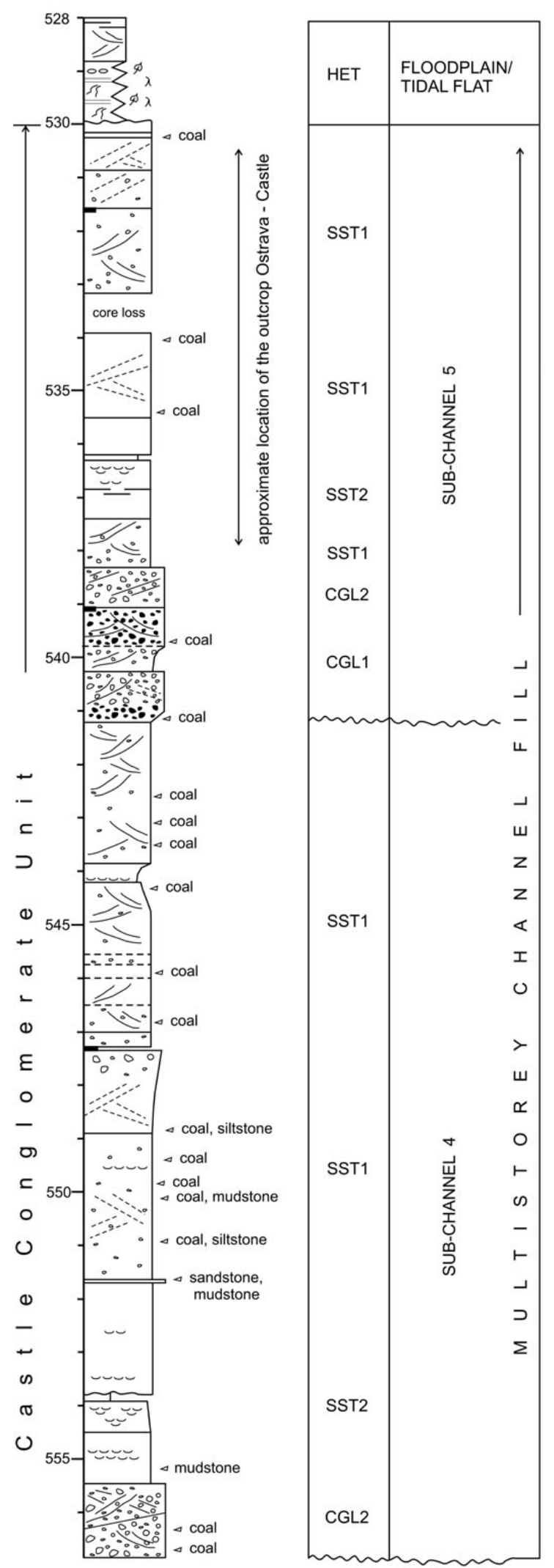

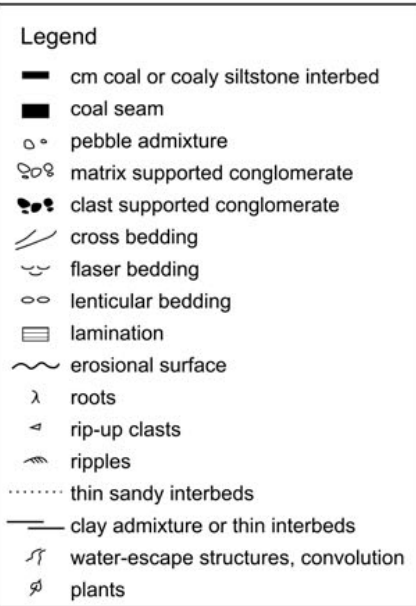

- $\mathrm{cm}$ coal or coaly siltstone interbed

- coal seam

0. pebble admixture

\$08 matrix supported conglomerate

?o: clast supported conglomerate

cross bedding

־ flaser bedding

oo lenticular bedding

$\boxminus$ lamination

$\sim$ erosional surface

$\lambda$ roots

$\triangle$ rip-up clasts

an ripples

..... thin sandy interbeds

- clay admixture or thin interbeds

ST water-escape structures, convolution

$\$$ plants

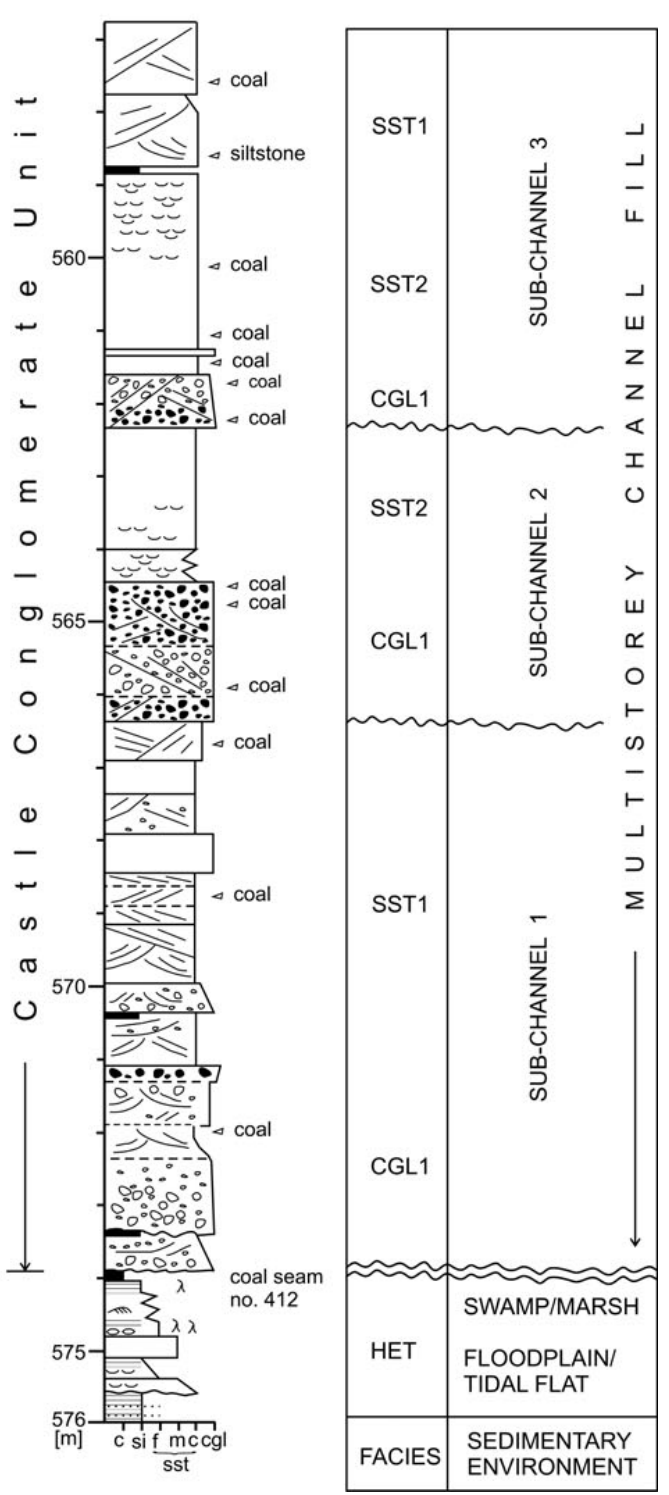

Figure 8. Measured section of core D 80-09 with interpreted sedimentary facies and environments. 

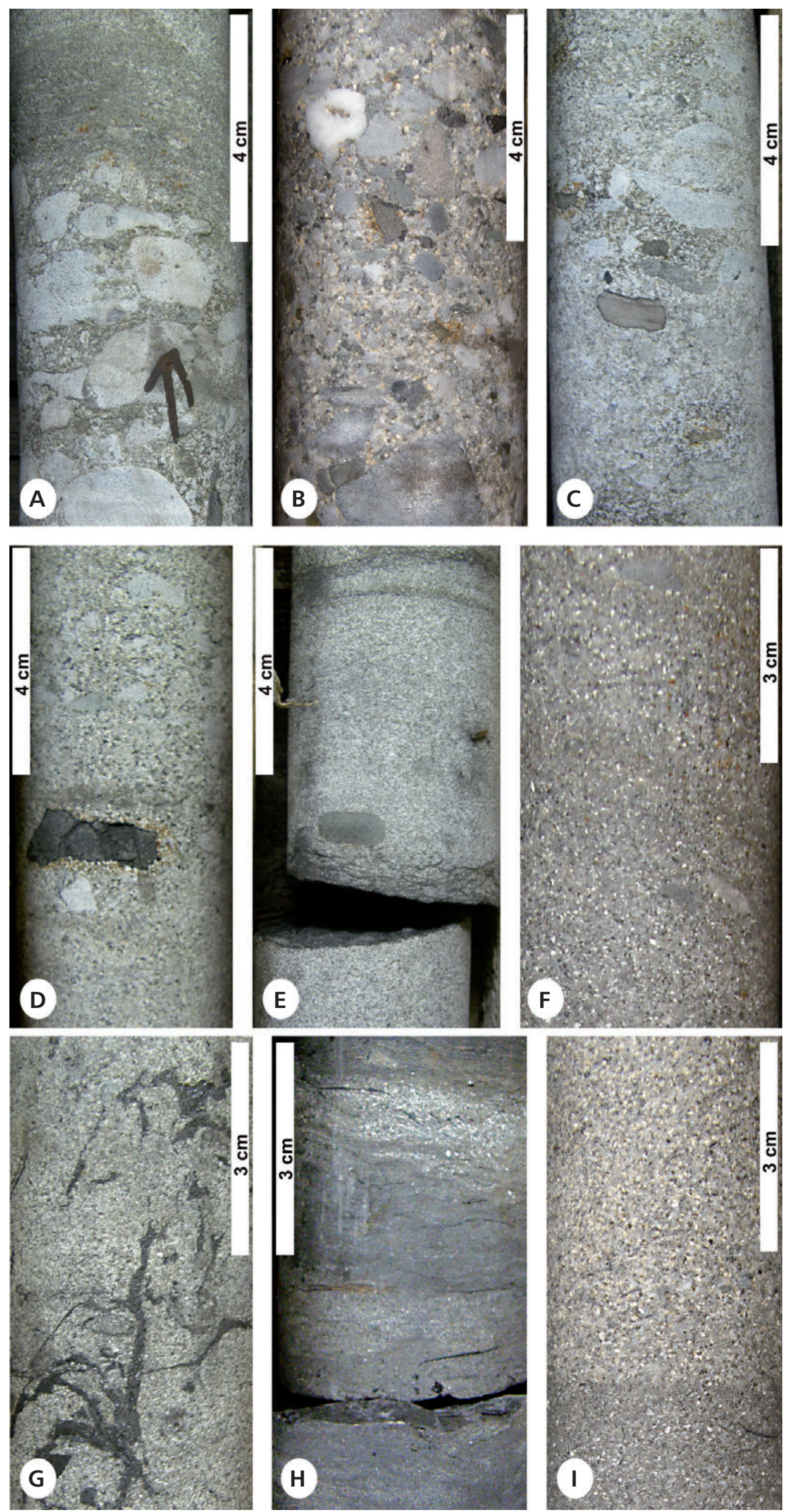

Figure 9. Photographs of the main facies in core $\mathrm{D} 80-09$. The core is $4 \mathrm{~cm}$ in diameter. - A - clast-supported oligomictic conglomerate with mostly well-rounded crystalline pebbles and cobbles, $571.15 \mathrm{~m}$, facies CGL1. • B - clast-supported polymictic conglomerate with well-rounded crystalline pebbles and cobbles and subangular siltstone rip-up pebbles, $566.25 \mathrm{~m}$, facies CGL1. $\bullet \mathrm{C}$ - polymictic matrix-supported conglomerate with siltstone rip-up clasts, $573.10 \mathrm{~m}, \mathrm{CGL} 2$. - D - coarsegrained sandstone with pebbles and coal rip-up clasts, $566.34 \mathrm{~m}$, SST1. • E - coarsegrained sandstone with mudstone and coal rip-up clasts and flaser bedding, $558.75 \mathrm{~m}$, SST1. - F - cross-bedded coarse-grained sandstone, $541.40 \mathrm{~m}$, SST1. • G - medium-grained sandstone with flaser bedding and coal drapes, $563.95 \mathrm{~m}$, SST2. - $\mathrm{H}$ - mudstone, siltstone and fine-grained sandstone interbeds with flaser and wavy bedding, coal drapes and rip-up clasts, structures partly obliterated by water escaping or pedogenesis, $529.85 \mathrm{~m}$, HET. - I - upper part of CGL2 facies represented by clayey pebbly coarse-grained sandstone sharply overlaid by well-sorted coarsegrained sandstone of SST1 facies, $538.30 \mathrm{~m}$. 

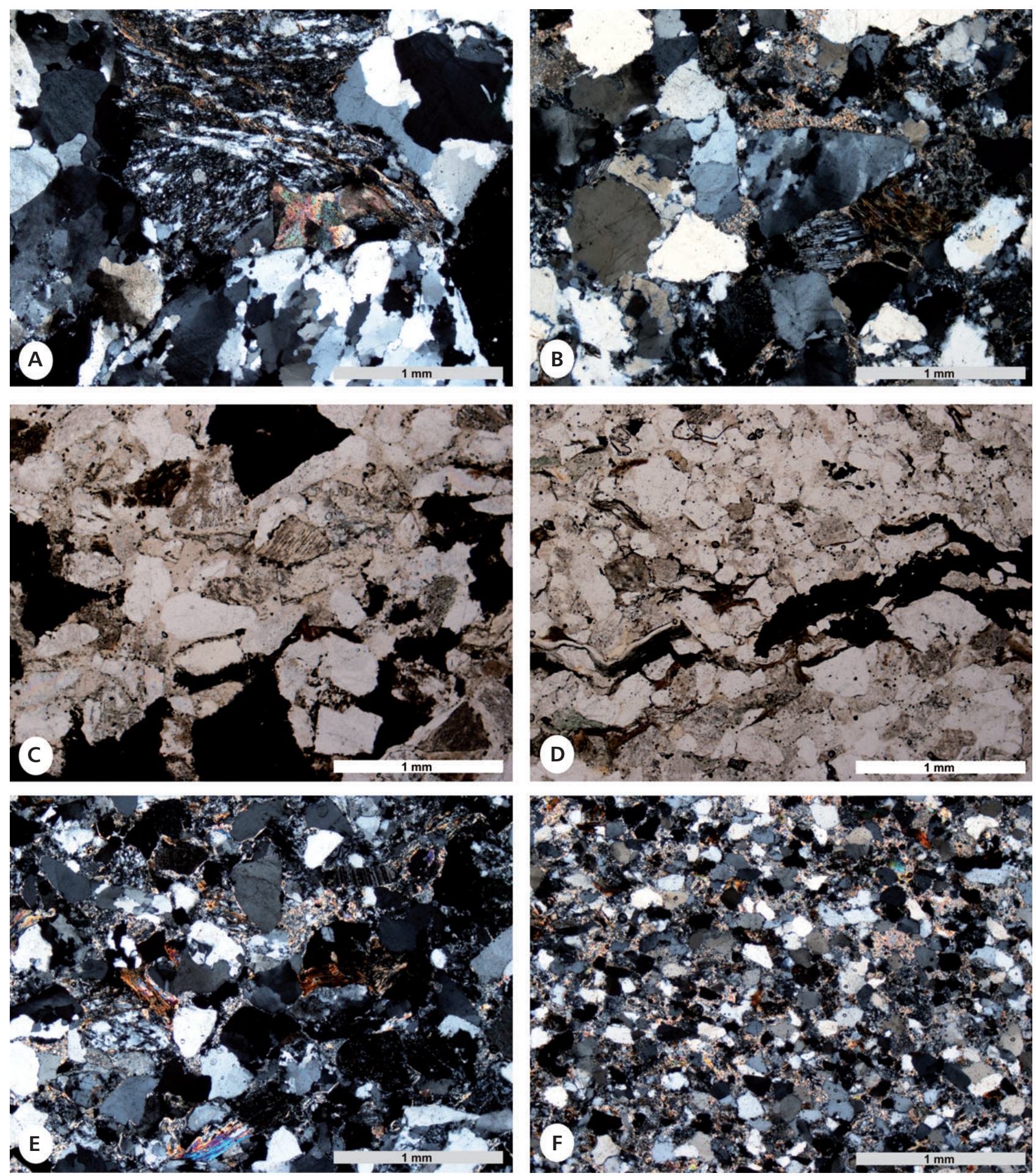

Figure 10. Microphotographs of the main facies in core D 80-09. All photographs have a longer side that is $3 \mathrm{~mm}$ long. A - facies CGL1, several polycrystalline quartz grains surrounding partly silicified and highly compacted siltstone (top centre), sample 5, 541.1 m, crossed nicols. $\bullet$ B - facies SST1, coarse-grained arcosic sandstone with subangular clasts, sample $1,530.1 \mathrm{~m}$, crossed nicols. $\bullet$ C - facies SST1, coarse-grained arcosic sandstone with coal rip-up clasts, sample $13,568.7 \mathrm{~m}$, single nicol. $\bullet \mathrm{D}$ - facies SST2, medium-grained sandstone with large muscovite flakes and coal drapes, both deformed by compaction, sample $8,554.3 \mathrm{~m}$, single nicol. $\bullet \mathrm{E}$ - facies SST2, medium-grained arcosic sandstone with. $\bullet \mathrm{F}-$ facies HET, fine-grained clayey moderately sorted sandstone, sample $20,574.9 \mathrm{~m}$. 

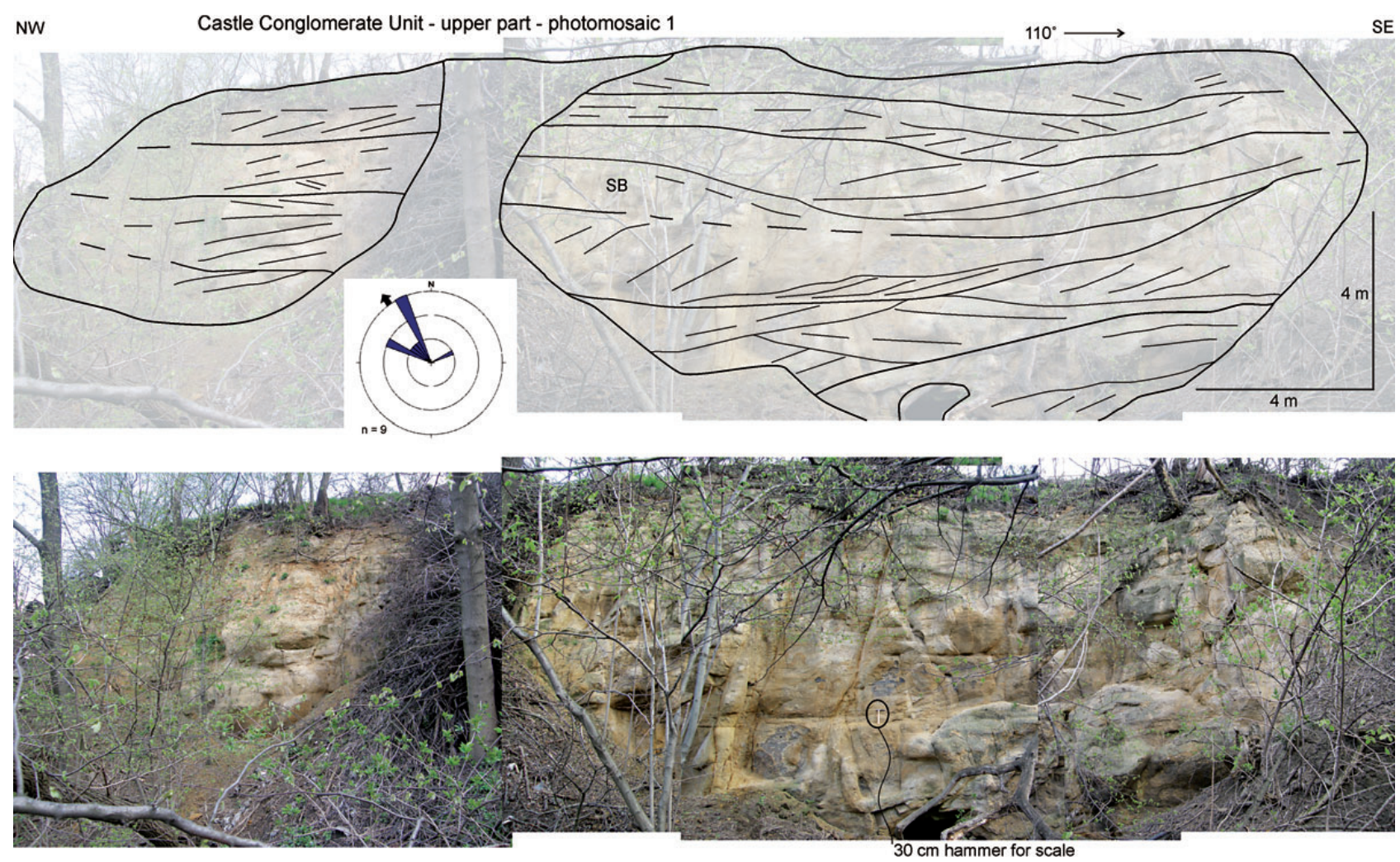

Figure 11. Outcrop ( $\left.\mathrm{N} 49^{\circ} 49^{\prime} 44.5^{\prime \prime} \mathrm{E} 018^{\circ} 18^{\prime} 15.0^{\prime \prime}\right)$ photomosaic with interpreted sediment body geometries. Channels are primarily filled with sand bedforms; sand bars (SB) also occur. Paleocurrent vectors show a low spread, and the main direction is to the NW-NNW. The black arrow represents the mean paleocurrent vector.

been caused by unique changes (glacieustatic or tectonic) that led to sedimentation from remote areas beyond the south-eastern edge of the basin.

\section{Depositional environments}

The lithologies, microstructures and sedimentary structures observed on the outcrop and in the cores indicate that traction currents are the main transporting mechanism. Sand body geometries correspond to fluvial channels. The absence of ripples, fine-grained deposits and point-bars, as well as the dominance of channel geometries and the low spread of paleocurrent vectors, support a low sinuosity (braided) river system. The Castle Conglomerate Unit represents a multi-storey channel fill of a low sinuosity (braided) river system.

Four main facies can be defined in the unit: clast-supported conglomerate, matrix-supported conglomerate, cross-bedded sandstone and flaser-bedded sandstone. These facies represent the different environments of a multistorey channel fill. Their occurrences confirm the speculations of Zeman \& Kupka (1958) and Dopita \& Havlena (1960) about the nature of the unit's sedimentation environment.
From both older reports (Zeman \& Kupka 1958) and new measurements (Figs 7 and 11), it appears that the direction of the unit's sedimentary material transport was approximately from south to north. This information is further evidence of the direction of the clastic material transport in the rocks of the Ostrava Formation. Together with an identical direction of transport in other lithostratigraphical units of the Ostrava Formation (Jansa 1967, Havlena 1982, Filák 2006), it appears that the direction of the transport from south to north functioned in parallel with the orogenic front from the Early Carboniferous (Kumpera \& Martinec 1995), at least until the end of the sedimentation of the Ostrava Formation. However, it is still questionable whether this was the only direction of material transport in the basin.

\section{Significance of the unit}

The Castle Conglomerate Unit's stratigraphic importance is not too large. In the places where this unit occurs (Fig. 7), it can serve as a local marker on the horizon. The existence of less significant phyto-paleontological changes in the conglomerate unit, presented by Šusta (1928b), is now supported by the work of Dybová \& Jachowicz (1957a, b), 


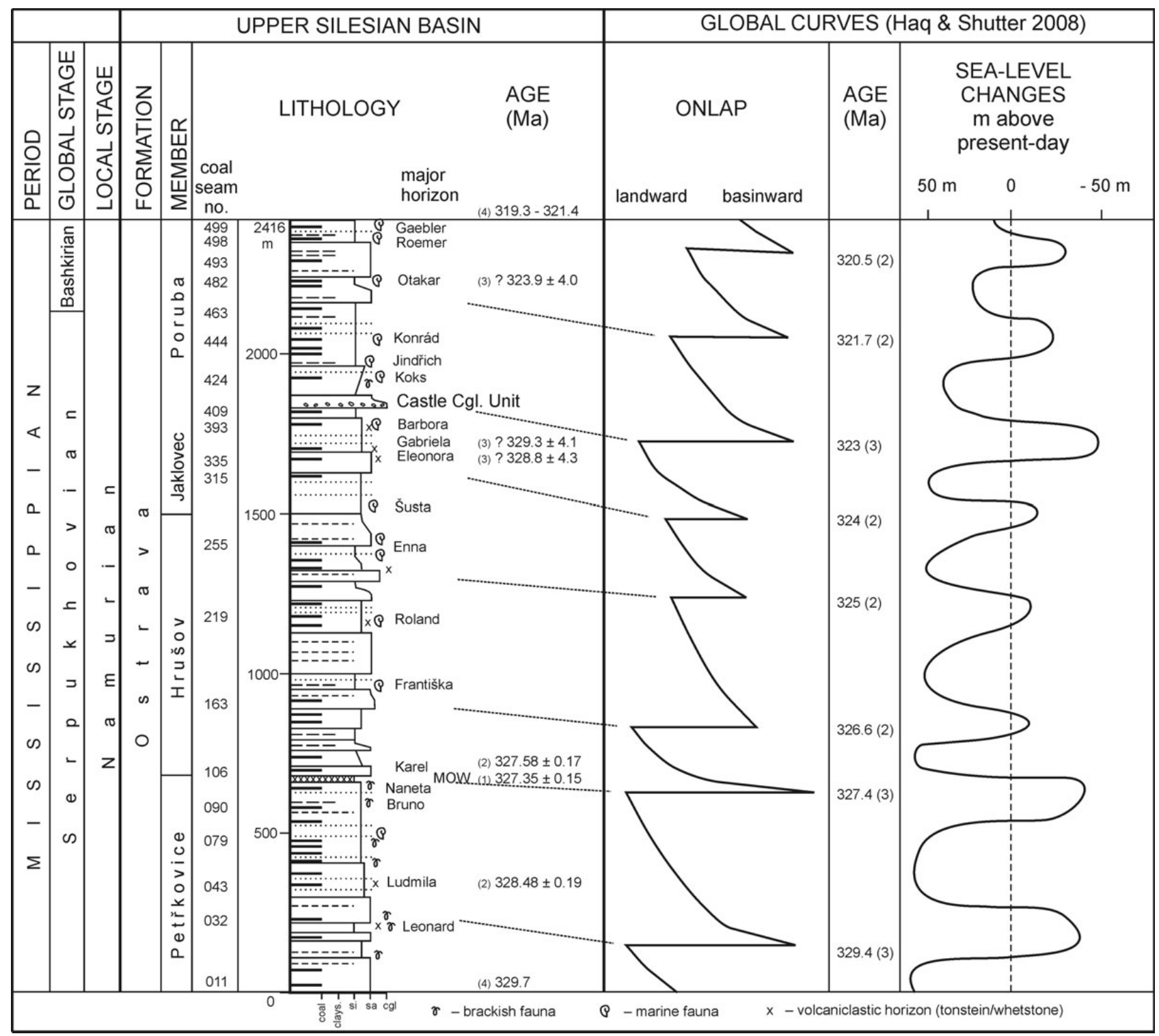

Figure 12. Hypothetical correlation of Ostrava Formation units with global glacioeustatic curves of sea level changes and the onlap of Haq \& Shutter (2008). Global curves show two prominent drops in the sea level that are correlated with the Castle Conglomerate unit (323 Ma) and the Main Ostrava Whetstone (MOW, 327.4 Ma). The lithology and paleontology of Petřkovice M. are based on well-log NP 308; Hrušov M. is from NP 251, Jaklovec M. is from NP 724 and NP 906, and Poruba M. is based on D-80/09. For the locations of the wells see Fig. 6. Geochronological data are from (1) U-Pb zircon CA-TIMS of Jirásek et al. (2013), (2) U-Pb zircon CA-TIMS of Gastaldo et al. (2009b) reinterpreted by Jirásek et al. (2013) and (3) Ar/Ar of Hess \& Lippolt (1986), reinterpreted by Gastaldo et al. (2009b). (4) was calculated using the CA-TIMS data in combination with cyclostratigraphic approach; see the text. A semiquantitative measure of the relative magnitude of each short-term global sea level event is shown in parentheses after the relevant age (medium (2) 25 to $75 \mathrm{~m}$; and major (3) $>75 \mathrm{~m}$ ).

who place the interface between Namurian microspore zones N6 and N7 (or IVb and V) into Seam No. 7 (413) in the direct base of the unit. Modern miospore research (Bek 2008), however, indicates a fairly steady change in communities that can be attributed to gradual changes in the environment. The work of Gastaldo et al. (2009b) also does not report a pronounced change in the Castle Conglomerate Unit.

\section{Inferred driving mechanisms}

The nearest horizons with data on their absolute age are the volcaniclastic horizons (tonsteins) of the Otakar (485) seam in the upper part of the Poruba Member and the Gabriela (365) seams in the Jaklovec Member. Their ${ }^{40} \mathrm{Ar} /{ }^{39} \mathrm{Ar}$ sanidine-based depositional ages were determined by Hess \& Lippolt (1986) and recalibrated by Gastaldo et al. (2009b) to $323.9 \pm 4.0 \mathrm{Ma}$ and $329.3 \pm 4.1 \mathrm{Ma}$, respecti- 
vely. These data are not very reliable because the sedimentation rates calculated using these data are substantially variable - from 116 to $686 \mathrm{~m} / \mathrm{Ma}$ - and not very useful for further discussion. According to recent $\mathrm{U}-\mathrm{Pb}$ zircon CA-TIMS dating of the Main Ostrava Whetstone (MOW), Karel and Ludmila horizons (see Fig. 12, Jirásek et al. 2013, and Gastaldo et al. 2009b), the $330 \mathrm{~m}$ thick interval between Ludmila tonstein and MOW dates to $1.13 \mathrm{Ma}$, which corresponds to a sedimentation rate of $292 \mathrm{~m} / \mathrm{Ma}$. These values are consistent with the sedimentation rate of the entire Ostrava Formation, which was $232 \mathrm{~m} / \mathrm{Ma}(2,416 \mathrm{~m}$ thickness, approximately $10 \mathrm{Ma}$ intervals, based on e.g., Gastaldo et al. 2009a). More interestingly, assuming that each coal seam represents a complete cyclothem, we can calculate the average duration of cyclothems within the Ludmila-MOW interval. This interval consists of 56 coal seams and spans the interval of $1.13 \mathrm{Ma}$, which yields a duration of $20.2 \mathrm{kyr}$ per cyclothem. This result could be interpreted as orbital forcing within the Milankovitch band of the axial precession climatic cycles. Assuming the same sedimentation rate for the entire Ostrava Fm., we dated the base of the Ostrava Fm. to $329.7 \mathrm{Ma}$; the same result is obtained using $20.2 \mathrm{kyr}$ per coal cyclothem (there are 43 coal seams below Ludmila). The top of the Ostrava Fm. yields a date of $321.4 \mathrm{Ma}$ when the $292 \mathrm{~m} / \mathrm{Ma}$ value is used (for the interval above MOW) or 319.3 using $20.2 \mathrm{kyr}$ per coal cyclothem (there are 456 coal seams above MOW).

The presence of the unit's coarse-grained clastics inside the basin fill, which is dominated by siltstone and medium-grained sandstone, indicates a major drop in the base level, which is interpreted here as a drop in the sea level. The event that caused the sedimentation of the Castle Conglomerate Unit cannot be correlated with tectonic events because we do not have independent evidence for major tectonic events. However, tectonic forcing for the CCU should not be ruled out. Certain tectonic influence is very likely in such a foreland basin. The deep erosion of the base of the CCU at the southern part of the basin (refer to the cross-section in Fig. 5) could be the result of a drop in the sea level.

Although we do not have sufficient reliable geochronological data, orbital climatic forcing appears to be the simplest explanation of the cyclothems' driving mechanism (Davydov et al. 2010, Pointon et al. 2012, Schmitz \& Davydov 2012, Sweet \& Soreghan 2012). The two major coarse-grained and most laterally persistent units of the Ostrava Formation are correlated with two major glacieustatic sea level drops (Haq \& Schutter 2008): the Castle Conglomerate Unit at $323 \mathrm{Ma}$ and the stratigraphic level of the Main Ostrava Whetstone at $327.4 \mathrm{Ma}$ (see Fig. 12). The CCU event can be connected with the glacieustatic drop of sea level during the onset of glaciation interval $\mathrm{C} 2$ of the Late Paleozoic Ice Age recognised by Fielding et al. (2008) in Australia as occurring
322.5-319.5 Ma. Alternatively, a sudden increase in humidity could theoretically cause such a sedimentary event (e.g., Martinsen et al. 1999, Leeder et al. 1998). Rapid slowing of the subsidence also can, theoretically, cause such drops of the base level in the sedimentary record, but it would be a much more gradual process; in a present state of geological knowledge we cannot find sufficient evidence for such a process in the Upper Silesian Basin.

\section{Conclusions}

The Castle Conglomerate Unit represents the most significant occurrence of coarse-grained sediments (medium- to coarse-grained sandstones and conglomerates) in the paralic Ostrava Formation of the Upper Silesian Basin. Other distinct horizons of coarse clastics are known to exist in the basin's fill in the overlying terrigenous units. Unlike the nearby, stratigraphically close oligomict conglomerates in the Saddle Member, polymict conglomerates occur in the Castle Conglomerate Unit (Dopita 1968). The strong petrographic dissimilarity of the conglomerates in the unit from the other Late Carboniferous conglomerates in the basin was also described by Kumpera \& Martinec (1995) and is interpreted here as the most prominent erosional event within the Ostrava Formation.

The Castle Conglomerate Unit is interpreted as sediment of a low sinuosity (braided) river system in a broad "valley"; four main facies were defined in this unit: clastsupported conglomerate, matrix-supported conglomerate, cross-bedded sandstone and flaser-bedded sandstone. These facies represent the different particular environments of a multistorey channel fill. The majority of paleocurrent vectors are oriented towards the NNW.

The presence of the unit's coarse-grained clastics inside the basin filling, which is dominated by siltstone and medium-grained sandstone, indicates a major drop in the base level, which is interpreted here as a drop in the sea level. We correlate this event with the major glacioeustatic sea level drop that occurred $323 \mathrm{Ma}$, which can be connected with the onset of glaciation interval C2 of the Late Paleozoic Ice Age.

\section{Acknowledgements}

This study was made possible by financial support within the grant projects "Geological questions of transition from paralic to terrigenous sedimentation mode in the Upper Silesian Basin and its correlation with other European Upper Carboniferous basins" (2012), which were financed by the Ministry of Education, Youth and Sports (projects SGS SP2012/24), and also by research project No. MSM 0021620855 that was financed by the same institution. We are grateful to Vítězslav Nešporek (DIAMO, state enterprise) for providing the coordinates of old mines. We also thank 
Green Gas DPB, a.s., which is part of the Green Gas International, B.V., and particularly Ivan Hoch, for access to the boreholes and documentation of the CCU. Detailed reviews of Luba Jansa, Jörg Schneider and Ondřej Bábek improved our manuscript considerably.

\section{References}

Banaś, M., Paszkowski, M. \& Clauer, N. 1995. K-Ar ages of white micas from the Upper Carboniferous rocks of Upper Silesian Coal Basin. Studia Geologica Polonica 108, $21-25$.

BEK, J. 2008. Late Mississippian-early Pennysylvanian (Serpukhovian-Bashkirian) miospore assemblages of the Bohemian part of the Upper Silesian Basin, Czech Republic. Review of Palaeobotany and Palynology 152(1-2), 40-57. DOI 10.1016/j.revpalbo.2008.04.008

Belt, E.S., Heckel, P.H., Lentz, L.J., Bragonier, W.A. \& Lyons, T.W. 2011. Record of glacial-eustatic sea-level fluctuations in complex middle to late Pennsylvanian facies in the Northern Appalachian Basin and relation to similar events in the Midcontinent basin. Sedimentary Geology 238(1-2), 79-100. DOI 10.1016/j.sedgeo.2011.04.004

Bishop, J.W., Montanez, I.P. \& Osleger, D.A. 2010. Dynamic Carboniferous climate change, Arrow Canyon, Nevada. Geosphere 6(1), 1-34. DOI 10.1130/GES00192.1

BRIDGE, J.S. 1993. Description and interpretation of fluvial deposits: a critical perspective. Sedimentology 40(4), 801-810. DOI 10.1111/j.1365-3091.1993.tb01361.x

BRIEDA, J. 1972. Hornicko-geologické problémy porubských vrstev v československé části hornoslezské černouhelné pánve. 121 pp. Ph.D. thesis, Vysoká škola báňská, Ostrava, Czech Republic. [in Czech]

Brieda, J., Grmela, A. \& PlášEK, O. 1973. Poruba-Schichten im Nordteil der Ostrauer Brachysynklinale. Časopis pro mineralogii a geologii 18(4), 399-404. [in Czech with German summary]

BuŁA, Z. \& ŻABA, J. 2005. Pozycja tektoniczna Górnośląskiego Zagłębia Węglowego na tle prekambryjskiego i dolnopaleozoicznego podłoża, 15-42. In JuReCZKA, J., BuŁA, Z. \& ŻABA, J. (eds) LXXVI Zjazd Naukowy Polskiego Towarzystwa Geologicznego. Państwowy Instytut Geologiczny, Warszawa. [in Polish]

DAvies, N.S. \& Gibling, M.R. 2011. Evolution of fixed-channel alluvial plains in response to Carboniferous vegetation. $\mathrm{Na}$ ture Geoscience 4(9), 629-633. DOI 10.1038/ngeo1237

Davydov, V.I., Crowley, J.L., Schmitz, M.D. \& Poletaev, V.I. 2010. High-precision U-Pb zircon age calibration of the global Carboniferous time scale and Milankovitch band cyclicity in the Donets Basin, eastern Ukraine. Geochemistry, Geophysics, Geosystems 11, Q0AA04. DOI 10.1029/2009GC002736.

Davydov, V.I., Korn, D. \& Schmitz, M.D. 2012. The Carboniferous Period, 603-651. In Gradstein, F.M., OGG, J.G., Schmitz, M.D. \& OGG, G.M (eds) The Geologic Time Scale 2012, Volume 2. Elsevier, Oxford.
Dembowski, Z. 1972a. General Information on the Upper Silesian Basin. Prace Instytutu Geologicznego 61, 9-22. [in Polish with English abstract]

Dembowski, Z. 1972b. The Cracow Sandstone Series of the Upper Silesian Coal Basin. Prace Instytutu Geologicznego 61, 509-538. [in Polish with English abstract]

Doktor, M. \& Gradziński, R. 1998. Deposition of the Zamecki Conglomerate (Poruba Beds, Upper Silesian Coal Basin), 7-10. In XXI Sympozjum Geologia formacji węglonośnych Polski. Wydawnictwo AGH, Kraków. [in Polish with English abstract]

DokTorowicz-Hrebnicki, S. 1935. Mapa szczegółowa Polskiego Zagłębia Węlowego 1:25.000. Arkusz Grodziec: Objaśnienie. 217 pp. Państwowy Instytut Geologiczny, Warszawa. [in Polish with French resume]

Dopita, M. 1959. Jednotný způsob označení uhelných sloji v ostravsko-karvinském revíru. MS, Sdružení OKD, Ostrava. [in Czech]

Dopita, M. 1968. Geological and Mining Problems of Exploiting Saddle Beds in the Ostrava-Karviná Coalfield. Přrirodovědecký sborník Ostravského kraje 24, 45-72. [in Czech with English summary]

Dopita, M., Aust, J., Brieda, J., Černý, I., Dvořák, P., Fialová, V., Foldyna, J., Grmela, A., Grygar, R., Hoch, I., HoněK, J., Kaštovský, V., KoneČnÝ, P., KožUŠníková, A., Krejčí, B., Kumpera, O., Martinec, P., Merenda, M., Müller, K., Novotná, E., Ptáček, J., Purkyñová, E., Řehoř, F., Strakoš, Z., TOMis, L., ToMší, J., VAlterovÁ, P., VAšíček, Z., Vencl, J. \& ŽídKovÁ, S. 1997. Geology of the Czech Part of the Upper Silesian Basin. 280 pp. Ministerstvo životního prostředí České republiky, Praha. [in Czech with English abstract]

Dopita, M. \& Havlena, V. 1960. Die stehenden Baumstämme und Baumstöcke in der oberen Schichtengruppe von Ostrava (Namurien A, Oberschlesisches Becken). Prírodovědný časopis slezský 21(3), 289-298. [in Czech with German summary]

Dopita, M. \& Kumpera, O. 1993. Geology of the OstravaKarviná coalfield, Upper Silesian Basin, Czech Republic, and its influence on mining. International Journal of Coal Geology 23(1-4), 291-321. DOI 10.1016/0166-5162(93)90053-D

Dvơ̆ÁK, J. 1994. Variscan flysch development in the Nizký Jeseník Mts. in Moravia and Silesia. Český geologický ústav, Praha. [in Czech with English summary]

Dybová, S. \& JaChowicz, A. 1957a. Microspore zones in Upper Silesian Productive Carboniferous. Kwartalnik geologiczny 1(1), 193-212. [in Polish with English summary]

Dybová, S. \& Jachowicz, A. 1957b. Microspore-Zones of the Carboniferous of the Ostrava-Karviná Region. Sborník Ústředního ústavu geologického, Oddíl paleontologický 24, 97-110. [in Czech with English summary]

Fielding, C.R., Frank, T.D., Birgenheier, L.P., Rygel, M.C., Jones, A.T. \& Roberts, J. 2008. Stratigraphic imprint of the Late Palaeozoic Ice Age in eastern Australia: a record of alternating glacial and nonglacial climate regime. Journal of the Geological Society 165(1), 129-140.

DOI 10.1144/0016-76492007-036

FILÁK, P. 2006. The influence of fluvial systems on the develop- 
ment of coal seams in the Petřkovice Member (lower part of Ostrava Formation, Namurian A, Czech part of the Upper Silesian Coal Basin). 133 pp. Ph.D. thesis, Vysoká škola báňská - Technical University of Ostrava, Czech Republic. [in Czech with English summary]

Gastaldo, R.A., Purkyňová, E. \& ŠImúnek, Z. 2009a. Megafloral perturbation across the Enna Marine Zone in the Upper Silesian Basin attests to late Mississippian (Serpukhovian) deglaciation and climate change. Palaios 24(6), 351-366. DOI 10.2110/palo.2007.p07-027r

Gastaldo, R.A., Purkyñová, E., Šimưnek, Z. \& Schmitz, M.D. 2009b. Ecological persistence in the Late Mississippian (Serpukhovian, Namurian A) megafloral record of the Upper Silesian Basin, Czech Republic. Palaios 24(6), 336-350. DOI 10.2110/palo.2008.p08-084r

Gibling, M.R. \& Wightman, W.G. 1994. Palaeovalleys and protozoan assemblages in a Late Carboniferous cyclothem, Sydney Basin, Nova Scotia. Sedimentology 41(4), 699-719. DOI 10.1111/j.1365-3091.1994.tb01418.x

Groves, J.R. \& Yue, W. 2009. Foraminiferal diversification during the late Paleozoic ice age. Paleobiology 35(3), 367-392. DOI 10.1666/0094-8373-35.3.367

GrygaR, R. \& VAVRo, M. 1995. Evolution of Lugosilesian Orocline (North-eastern periphery of the Bohemian Massif): Kinematics of Variscian deformation. Journal of the Czech Geological Society 40(1-2), 65-90.

Hampson, G., Stollhofen, H. \& Flint, S. 1999. A sequence stratigraphic model for the Lower Coal Measures (Upper Carboniferous) of the Ruhr district, north-west Germany. Sedimentology 46(6), 1199-1231. DOI 10.1046/j.1365-3091.1999.00273.x

HaQ, B.U. \& SchutTer, S.R. 2008. A Chronology of Paleozoic Sea-Level Changes. Science 322, 64-68.

DOI 10.1126/science. 1161648

Havlena, V. 1982. The Namurian deposits of the Upper Silesian Basin. Rozpravy Československé akademie věd, Řada matematických a prírodních věd 92(7), 1-41.

Havlena, V. 1988. The cyclicity of the Namurian coal-bearing strata in Upper Silesia. Časopis pro mineralogii a geologii 33(4), 357-369.

Henry, L.C., Isbell, J.L., Limarino, C.O., McHenry, L.J. \& Frasier, M.L. 2010. Mid-Carboniferous deglaciation of the Protoprecordillera, Argentina recorded in the Agua de Jagüel palaeovalley. Palaeogeography, Palaeoclimatology, Palaeoecology 298(1-2), 112-129.

DOI 10.1016/j.palaeo.2010.03.051

Hess, H.J. \& Lippolt, J.C. 1986. ${ }^{40} \mathrm{Ar} /{ }^{39} \mathrm{Ar}$ ages of tonstein and tuff sanidines: New calibration points for the improvement of the Upper Carboniferous time scale. Chemical Geology 59, 143-154.

HÝlovÁ, L., JureczKa, J., JiRÁSEK, J., Sivek, M. \& HotÁrkovÁ, J. 2013. The Petřkovice Member (Ostrava Formation, Mississippian) of the Upper Silesian Basin (Czech Republic and Poland). International Journal of Coal Geology 106, 11-24. DOI 10.1016/j.coal.2013.01.004

JANSA, L. 1967. Sedimentological evolution of Carboniferous Formations in the southern part of the Upper Silesian Basin.
247 pp. Ph.D. thesis, Vědecko-výzkumný uhelný ústav Ostrava, Czech Republic. [in Czech]

JANSA, L. \& TomŠík, J. 1960. Použití metody faciálně cyklické analýzy v ostravsko-karvinském karbonu. Pracovní metody geologické služby 1, 497-518.

Jerrett, R.M., Flint, S.S., Roy, D.C. \& Hodgson, D.M. 2011. Sequence stratigraphic interpretation of a Pennsylvanian (Upper Carboniferous) coal from the Appalachian Basin, USA. Sedimentology 58(5), 1180-1207. DOI 10.1111/j.1365-3091.2010.01200.x

Jirásek, J., HÝlová, L., SiveK, M., JureczKa, J., MartíneK, K., SÝkorovÁ, I. \& SchmitZ, M. 2013. Major Mississippian volcaniclastic unit of the Upper Silesian Basin, the Main Ostrava Whetstone: composition, sedimentary processes, palaeogeography and geochronology. International Journal of Earth Sciences 102, 989-1006. DOI 10.1007/s00531-012-0853-5

JuRECZKA, J. 1988. Nowe dane o charakterystyce litostratygraficznej kontaktu serii paralicznej i górnoślaskiej serii piaskowcowej karbonu zachodniej części Górnosląskiego Zagłebia Węgłowego, 41-66. In XI Sympozjum Geologia formacji węglonośnych Polski. Wydawnictwo AGH, Kraków. [in Polish]

Jureczka, J., Dopita, M., GaŁka, M., Krieger, W., Kwarciński, J. \& MartineC, P. 2005. Geological Atlas of Coal Deposits of the Polish and Czech Parts of the Upper Silesian Coal Basin. 31 pp. Państwowy Instytut Geologiczny \& Ministerstwo Środowiska, Warszawa.

JureCZKa, J. \& Kotas, A. 1995. Coal deposits - Upper Silesian Coal Basin. Prace Państwowego Instytutu Geologicznego 148, 164-173.

Kalvoda, J., Bábek, O., Fatka, O., Leichmann, J., Melichar, R., NeHYBA, S. \& ŠPAČEK, P. 2008. Brunovistulian terrane (Bohemian Massif, Central Europe) from late Proterozoic to late Paleozoic: a review. International Journal of Earth Sciences 97, 497-518. DOI 10.1007/s00531-007-0183-1

Kandarachevová, J., HÝlová, L. \& SedláčKová, L. 2008. Possibilities of utilization of software tools in modelling of development of geological parameters in the study of geology of coal basins, 27-29. In Geo-Sympozjum Młodych Badaczy Silesia 2008, Wspótczesne Trendy w naukach o Ziemi, 5.-7.11. 2008, Złoty Potok. Wydział Nauk o Ziemi Uniwersytetu Śląskiego, Sosnowiec.

Kandarachevová, J., SedláčKová, L., HÝlová, L, Jirásek, J. \& SiveK, M. 2009. Lateral development of coalification in the Czech part of the Upper Silesian Coal Basin and its connection with gas deposits. International Journal of Coal Geology 78(3), 225-232. DOI 10.1016/j.coal.2009.02.002

KęDZior, A., Gradziński, R., DokTor, M. \& GMur, D. 2007. Sedimentary history of a Mississippian to Pennsylvanian coalbearing succession: an example from the Upper Silesia Coal Basin, Poland. Geological Magazine 144(3), 487-496. DOI 10.1017/S001675680700341X

Kotas, A. 1995. Lithostratigraphy and sedimentologic-paleogeographic development - Upper Silesian Coal Basin. Prace Państwowego Instytutu Geologicznego 148, 124-134.

Kotas, A., BuŁA, Z. \& JuRECZKa, J. 1988. Problematyka podziału litostratygraficznego Górnosląskiej serii piaskowcowej 
karbonu GZW w świetle zasad kodeksu stratygraficznego, 55-61. In XI Sympozjum Geologia formacji weglonośnych Polski. Wydawnictwo AGH, Kraków. [in Polish]

Kotas, A. \& MalczyK, W. 1972a. The Paralic Series of the Lower Namurian Stage of the Upper Silesian Coal Basin. Prace Instytutu Geologicznego 61, 329-426. [in Polish with English abstract]

Kotas, A. \& MalczyK, W. 1972b. The Upper Silesian Sandstone Series of the Upper Namurian Stage of the Upper Silesian Coal Basin. Prace Instytutu Geologicznego 61, 427-466. [in Polish with English abstract]

Kumpera, O. 1990. Outline of the Paleozoic sediments below the Upper Silesian Carboniferous coal-bearing molasse in Upper Silesian Basin. Sborník vědeckých prací Vysoké školy báňské

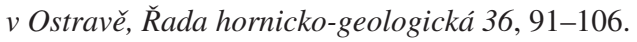

Kumpera, O. 1997. Controls on the evolution of the Namurian paralic basin, Bohemian Massif, Czech Republic, 13-27. In GAYER, R. \& PEŠEK, J. (eds) European Coal Geology and Technology. Geological Society of London, Special Publication 125 .

Kumpera, O. \& Martinec, P. 1995. The development of the Carboniferous accretionary wedge in the Moravian-Silesian Paleozoic Basin. Journal of the Czech Geological Society 40(1-2), 47-64.

LEEDER, M.R., HARRIS, T. \& KIRKBY, M.J. 1998. Sediment supply and climate change: implications for basin stratigraphy. Basin Research 10(1), 7-18. DOI 10.1046/j.1365-2117.1998.00054.x

Martinec, P., JirÁsek, J., Kožušníková, A. \& Sivek, M. (eds) 2005. Atlas of coal - the Czech part of the Upper Silesian Basin. 64 pp. Anagram, Ostrava. [in Czech with English abstract]

Martinsen, O.J., Ryseth, A., Helland-Hansen, W., Flesche, H., TorkildsEn, G. \& IDIL, S. 1999. Stratigraphic base level and fluvial architecture: Ericson Sandstone (Campanian), Rock Springs Uplift, SW Wyoming, USA. Sedimentology 46(2), 235-259. DOI 10.1046/j.1365-3091.1999.00208.x

MiALL, A.D. 1985. Architectural-element analysis: a new method of facies analysis applied to fluvial deposits. Earth-Science Reviews 22(4), 261-308.

DOI 10.1016/0012-8252(85)90001-7

OpLuštiL, S. 2005. Evolution of the Middle Westphalian river valley drainage system in central Bohemia (Czech Republic) and its palaeogeographic implication. Palaeogeography, Palaeoclimatology, Palaeoecology 222(3-4), 223-258. DOI 10.1016/j.palaeo.2005.03.016

PAszKowski, M. 1994. New data about lithology and provenance of exotic pebbles from Poruba and Saddle Beds of western part of Upper Silesian Coal Basin, 47-56. In KonEČnÝ, P. \& MARTINEC, P. (eds) Sborník referátů 2. česko-polské konference o sedimentologii karbonu hornoslezské pánve. Ústav geoniky AV ČR, Ostrava. [in Polish with English abstract]

Paszkowski, M., Jachowicz, M., Michalik, M., Teller, L., Uchman, A. \& Urbanek, Z. 1995. Composition, age and provenance of gravel-sized clasts from the Upper Carboniferous of the Upper Silesia Coal Basin (Poland). Studia Geologica Polonica 108, 45-127.

PEŠEK, J. \& SÝKorovÁ, I. 2006. A review of the timing of coalification in the light of coal seam erosion, clastic dykes and coal clasts. International Journal of Coal Geology 66(1-2), 13-34. DOI 10.1016/j.coal.2005.05.010

Petrascheck, W. 1910. Das Alter der Flöze in der Peterswalder Mulde und die Natur der Orlauer und der Michálkowitzer Störung im Mährisch-Ostrauer Steinkohlenrevier. Jahrbuch der Kaiserlich-königlichen geologischen Reichsanstalt 60(4), 779-814.

Pointon, M.A., Chew, D.M., Ovtcharova, M., Sevastopulo, G.D. \& CRowley, Q.G. 2012. New high-precision U-Pb dates from western European Carboniferous tuffs; implications for time scale calibration, the periodicity of late Carboniferous cycles and stratigraphical correlation. Journal of the Geological Society 169(6), 713-721. DOI 10.1144/jgs2011-092

PoRZYCKI, J. 1972. The Siltstone Series of the Lower Westphalian Stage of the Upper Silesian Coal Basin. Prace Instytutu Geologicznego 61, 467-508. [in Polish with English abstract]

Powell, M.G. 2008. Timing and selectivity of the Late Mississippian mass extinction of brachiopod genera from the Central Appalachian Basin. Palaios 23(7-8), 525-534. DOI 10.2110/palo.2007.p07-038r

PŘIBYL, A. 1954. Cyklická sedimentace v ostravsko-karvinském kamenouhelném revíru. Sborník Ústředního ústavu geologického 21, 57-82. [in Czech]

Rygel, M.C., Fielding, C.R., Frank, T.D. \& Birgenheier, L.P. 2008. The magnitude of Late Paleozoic glacioeustatic fluctuations: a synthesis. Journal of Sedimentary Research 78(7-8), 500-511. DOI 10.2110/jsr.2008.058

ŘEног̆, F. 1970. Die Goniatiten-Zonen der Ostrava-Schichtengruppe (Namur A). Věstník Ústředního ústavu geologického 45, 213-216. [in German]

Řehoř, F. \& ŘReHořovÁ, M. 1985. Faunistické horizonty porubských vrstev ostravského souvrství moravské části hornoslezské pánve. Acta Facultatis paedagogicae ostraviensis 94, 63-81. [in Czech]

SchmitZ, M.D. \& DAvydov, V.I. 2012. Quantitative radiometric and biostratigraphic calibration of the Pennsylvanian Early Permian (Cisuralian) time scale and pan-Euramerican chronostratigraphic correlation. Geological Society of America Bulletin 124(3-4), 549-577. DOI 10.1130/B30385.1

SedláČKovÁ, L., JiRÁSEK, J., RoJÁkovÁ, T. \& SiveK, M. 2007. „Zámecký“ Conglomerate - An Important Event in the Development of the Poruba Member (Lower Namurian) in the Czech Part of the Upper Silesian Basin, 125-132. In XXX Sympozjum Geologia formacji węlonośnych Polski. Wydawnictwo AGH, Kraków.

Sivek, M., Dopita, M., Krưl, M., Č́́slavský, M. \& Jirásek, J. 2003. Atlas of Chemical-Technological Properties of Coals in the Czech Part of the Upper Silesian Basin. 31 pp. Vysoká škola báňská - Technical University of Ostrava, Ostrava.

SкоС̆ЕK, V. 1991. Indications of the Late Carboniferous eustatic and climatic oscillations in the Upper Silesian Basin. Věstník Ústředního ústavu geologického 66(2), 85-95.

StrakošovÁ, O. 1973. Výsledky hlubokého strukturního vrtu SV 2 Stonava. Sborník GPO 3, 51-66. [in Czech]

SweEt, D.E. \& Soreghan, G.S. 2012. Estimating magnitudes of relative sea-level change in a coarse-grained fan delta system: 
Implications for Pennsylvanian glacioeustasy. Geology 40(11), 979-982. DOI 10.1130/G33225.1

ŚwierczewsKa, A. 1995. Composition and provenance of Carboniferous sandstones from the Upper Silesia Coal Basin (Poland). Studia Geologica Polonica 108, 27-43.

ŠEVČí, V. 1989. Současné poznatky o redukci mocnosti stratigrafických jednotek ostravského souvrství v československé a polské části hornoslezské černouhelné pánve. Uhli 37(3), 120-124. [in Czech]

Šusta, M. 1928a. Rozdělení uhlonosného karbonu ostravsko-karvinské oblasti. Hornický věstník a Hornické a hutnické listy 10(16), 187. [in Czech]

Šusta, M. 1928b. Stratigrafie ostravsko-karvinské kamenouhelné oblasti ve světle paleontologie, 341-429. In Kamenouhelné doly ostravsko-karvinského revíru. Ǩeditelská konference ostravsko-karvinského kamenouhelného revíru v Moravské Ostravě, Moravská Ostrava. [in Czech]
Waters, C.N. \& Condon, D.J. 2012. Nature and timing of Late Mississippian to Mid-Pennsylvanian glacio-eustatic sea-level changes of the Pennine Basin, UK. Journal of the Geological Society 169(1), 37-51. DOI 10.1144/0016-76492011-047

Zeman, J. 1960. Megacyclothems in the Ostrava-Karviná District. Věstník Ústředního ústavu geologického 35, 299-313. [in Czech with English summary]

Zeman, J. \& Kupka, J. 1958. Die Frage der Genesis und der stratigraphischen Bedeutung des Zámek-Konglomerats in den oberen Ostrava-Schichten. Věstník Ústředního ústavu geologického 33, 274-278. [in Czech with German summary]

Žídková, S., Krejčí, B., Martinec, P., Dopita, M. \& Brieda, J. 1997. Ostravské souvrství, 43-87. In DopitA, M. (ed.) Geology of the Czech Part of the Upper Silesian Basin. Ministerstvo životního prostředí České republiky, Praha. [in Czech with English abstract] 